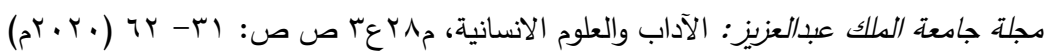
DOI:10.4197/Art.28-3.2

\title{
المفاهيم الحديثة في العقوبات البديلة عن الأحكام التعزيرية
}

\author{
عنود محمد عبد المحسن الخضيري

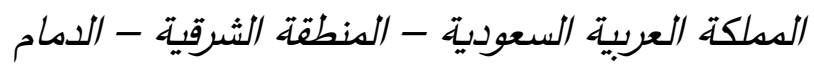 \\ أستاذ مساعد بقسم الدراسات الإسلامية الإنية

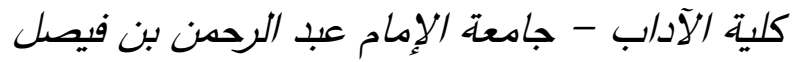

مستخلص. سلطت الضوء في هذا البحث على العقوبات البديلة للأحكام التعزيرية غير المقدرة من الثارع، مبينة

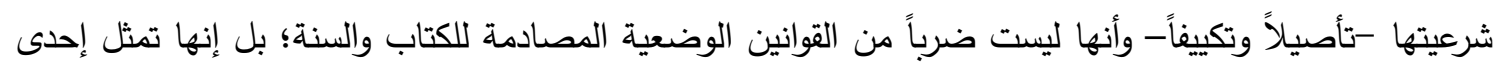

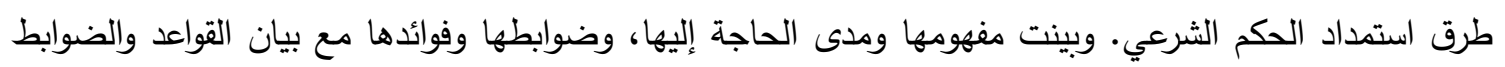
الفقهية التي تتخرج عليها، ومعوقات تفعيلها، ثم ذكرت أمثلة لها، كما عرجت على على بيان وضيان العلاقة بينها وبين التعازير . وتوصلت لنتائج منها:

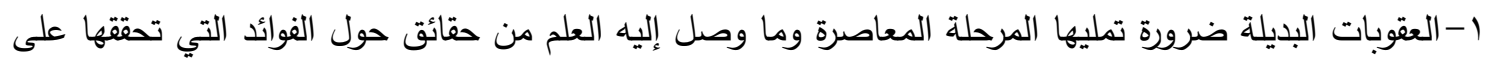

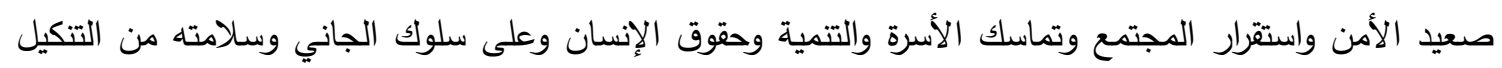
والإيلام البدني والنفسي.

r- العقوبات البديلة لا تتسحب إلا على أبواب التعازير وهي ما لا نص شئل شرعياً في تقدير عقوبتها.

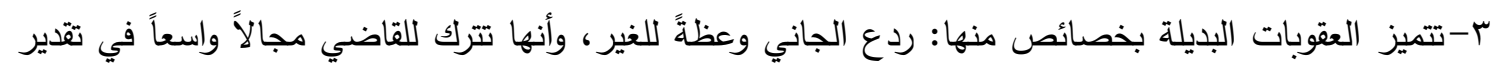

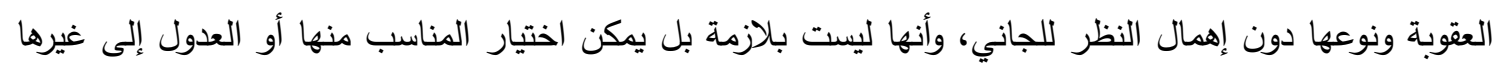
مما ليس فيه خروج على أحكام الثريعة وروحها.

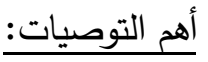

ا-ب-الاهتمام بنشر الوعي الاجتماعي بأهمية العقوبات البديلة في المجتمع عن طريق الدورات والبرامج المختلفة.

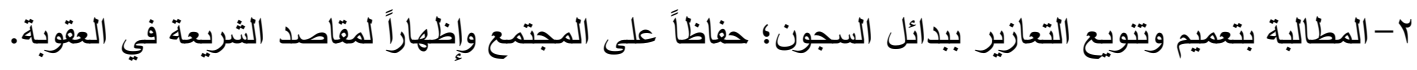

يجب التقيد بها، ومن لم يتقيد بها كان مخالفاً وكان

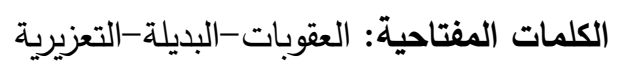
للحاكم أن يعاقب أو يعفو. لا شك أن نظام العقوبات في الإسلام يشمل الأوامر والمخالفات ليس لها أنواع محصورة بل هي ني أي قانون

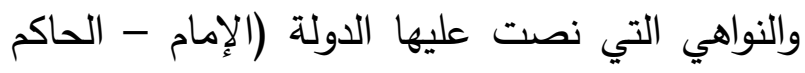
- أو من ينوب عنهم) وهي فرض على المسلمين صدر عن الدولة وتم تجاوزه أو التعدي عليه، وهذه 
الأول: لا يوجد فيه نص شرعي؛ إذ بابه واسع في الاجتهاد وليس توقيفياً.

والثاني: هو مرتبط بحال المتهم وملابسات قضيته. وإذا علمنا أن العقوبات التعزيرية لا يوجد محدد لها شرعاً بعكس القضايا الحدودية فان هذا يفتح الباب لمصطلح جديد هو العقوبات البديلة عن الأحكام التعزيريـة، وهذه البديلة تأتي تحت ما يسمى لت بالمصلحة العامة التي جاءت الثريعة بدعمها فيما لا يخالف الأحكام المحددة شرعاً. ولا يُتصور مصطلح العقوبات البديلة بأنه بديل للحكم النصي أو الخروج عنه وتجاوز له وتعدي على أحكام الشريعة؛ إذ أن فقه مقاصد الشريعة يعتبر من أهم آليات تجديد الفقه وتطويره، والتجديد الذي نسعى إليه ليس معناه التبديل، فالثوابت باقية وملزمة، ولكن فتح باب الاجتهاد أصبح من الواجبات خاصة في ظل المتغيرات المعاصرة والنوازل الواقعة [']

\section{أهمية البحث}

ا-العقوبات البديلة تعد من فقه المستجدات والنوازل التي تُنَّل فيها النصوص على الواقعة الجديدة التي لم تكن من قبل-؛ لكونها من باب التعزير ، والتعزير في الشريعة يدور مع المصلحة وجوداً وعدماً، ويمكن لكل مجتمع في كل زمان ومكان أن يوقع التعزيرات المناسبة التي تكفل صلاح المجتمع والأمة-. وإعمال لفقه الموازنات وفق قاعدة المصالح والمفاسد ومن
المخالفات يسميها الفقهاء جرائم التعزير، والتي هي في الواقع محظورات شرعية ليس لها عقوبة مقدرة من قبل الشارع مثل: الخلوة بالمرأة الأجنبية، وأكل الربا، والقذف بغير الزنا، والثتم والسباب، والتطفيف في الكيل والميزان... ونحو ذلك. وترك تحديد العقوبة نوعاً ومقداراً مفوضاً إلى اجتهاد القاضي حتى تكون العقوبة محققة للغرض من تشريعها. ولا يصدر رأيه عن هوى، وإنما يلاحظ جسامة الجريمة وظروفها ومقدار ضررها وحال الجاني من كونه ارتكب جريمة أو لا أو كونه من ذوي السوابق والإجرام. ومن المعلوم أن الشريعة جاءت بمبادئ عامة وقواعد كلية، وبتطبيق هذه القاعدة على نظام العقوبات نجد الشريعة بينت بالنص القاطع لجرائم العقوبات الثابتة كوالتي لا يخلو منها مجتمع ولا تتغير صورتها؛ لصلتها بثبات الطبيعة العامة للإنسان والتي بتطبيقها يحصل الأمن

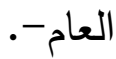

أما غير هذه الجرائم فقد واجهتها بالنص على المبدأ العام القاضي بالتجريم وتركت العقوبة للسلطة المختصة -كما أسلفت-. ونحن نعلم بأن العقوبات لم تشرَّع للانتقام أو التشفي أو الامتهان لكرامة الإنسان؛ بل لحماية المجتمع من المخاطر التي تهدد أخلاقه وأمنه؛ لذا لا يكاد يخلو نظام في العالم من أنظمة عقابية أو جزائية. أما نظام التعزير في العقوبات فهو مما انفردت به الثريعة الإسلامية، والعقوبات البديلة مرتبطة بالتعازير من وجهين: 
أسباب اختيار الموضوع

1- تصحيح الاعتقاد الخاطئ من عامة الناس بأن لفظ العقوبات البديلة هو إقصاء للحكم الثرعي لفظاً ومحلاً؛ لكونها بديلة للأحكام النصية في نظرهم بل ويصفون اللجوء إليها بالاستخفاف بشعائر الله تعالى وتمرداً على أحكامه وعلى الأنظمة التي سنها ولي الأمر ولا يخفى ما في ذلك من الجهل الفاضح. r-إعطاء الرأي الإسلامي العام والموقف الفقهي الإجمالي لهذه العقوبات على صعيد التحقيق العلمي والتأصيل الاجتهادي وتقديم الحلول الثرعية المناسبة والمقاربات الاجتهادية الممكنة.

ب-إن قضاء المملكة مستهدف ومتربص من بعض المتطرفين الذين يحاولون التشكيك في شرعية قوانينه وعقوباته ويرمونها بالوضعية المصادمة للكتاب والسنة.

ع -الاهتمام الدولي بالاتجاه إلى توسيع نطاقه وزيادة العمل به بصورة مطردة؛ لما لهذه الإحكام من آثارها الايجابية على المدى البعيد ودورها العميق في البعد السلوكي لمرتكبي الجرائم. 0-التبصرة بأن قضائنا يعتمد تحكيم الشريعة الإسلامية التي تقضي قواعدها بالأخذ بالمقاصد والغايات وعدم الأخذ بالمنهج المجرد للظاهر •

\section{إثكالية البحث}

تتمثل مشكلة البحث في السؤال الآتي: هل العقوبات البديلة تعتبر بديلاً عن الأحكام الشرعية المقرة
ذلك عدم دخول أرباب الجرائم الكبيرة والخطرة في

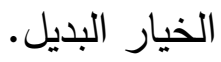
r-بيان شمولية وصلاحية الشريعة لكل زمان ومكان وإبراز محاسنها ومرونتها لاسيما في الجوانب الجنائية والقضائية مع بيان أن من أهم الثوابت التي يقوم عليها ديننا الحنيف أنه يحدد لولي الأمر القواعد العامة التي لا تختلف باختلاف المكان أو الزمان، وترك تحديد الأحكام الخاصة لله والجزئيات الدقيقة والتي لا شك أنها في تغير دائم. ب-تظهر أهمية العقوبات البديلة في كونها تمثل مظهراً من مظاهر التيسير في الثريعة الإسلامية التي تقوم على اليسر، ويوصلنا إلى أن بقاء الحكم على ما كان عليه يلزم منه المشقة والضرر بالناس وهذا مخالف لقواعد الثريعة التي تدعو إلى التخفيف ورفع الحرج.

ع-أصبح للعصر ضروراته وحاجاته، وهذه وتلك ينبغي أن تقرض على الفقيه الاتجاه إلى مراعاة الواقع والاجتهاد له في الأحكام الفرعية سواء في العبادات أو المعاملات او الأحوال الشخصية أو الو 0-تمييز السياسة العقابية في الشريعة الإسلامية التي تهدف إلى السمو بالإنسان وحمايته - عن منظومات القوانين الوضعية التي لا تراعي المصالح والإطار الأخلاقي التشريعي. 
بالكتاب والسنة وإقصاءً لها؟ ويتفرع عن هذه إلى تجميع متفرق دفعت توهم كونها بديلاً عن الأحكام الثرعية.

\section{خطة البحث}

اشتمل البحث على ثلاثة مباحث وخاتمة:

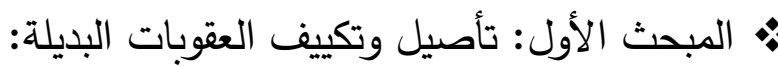

$$
\text { ويشتمل على مطلبين: }
$$

•المطلب الأول: مفهوم الأحكام البديلة ومدى علئي

$$
\text { الحاجة إليها -ويشتمل على مسألتين-: }
$$

- - المسألة الأولى: المقصود بالأحكام البديلة وأنواع

$$
\text { الجرائم التي تدخل فيها. }
$$

- المسألة الثانية: مشروعية تطبيق العقوبات لمات ل البديلة في الشريعة الإسلامية. •المطلب الثاني: القواعد والضوابط الفقهية التي لني تتخرج عليها العقوبات البديلة.

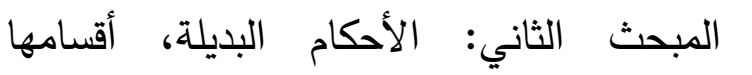

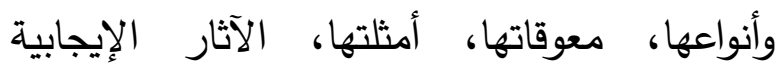
للعقوبات البديلة.

ويشتمل على أربعة مطالب: •المطلب الأول: أقسام وأنواع العقوبات البديلة.

•المطلب الثاني: معوقاتها. •المطلب الثالث: أمثلة العقوبات البديلة. •المطلب الرابع: الآثار الإيجابية للعقوبات البديلة.

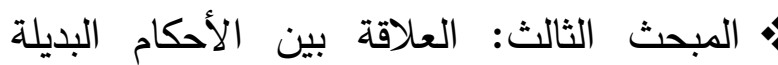

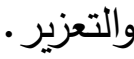

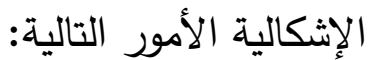
الأول: هل هذه البدائل منضبطة بضوابط الثرع؟ وما مدى موائمتها للواقع? هذه البدان الثاني: الفرق بينها وبين التعازير، وماهي الآثار الإيجابية لتفعيلها على الفرد والمجتمع. الدراسات السابقة وما يضيفه البحث إليها 1- العقوبات البديلة في الفقه الإسلامي: محمد محمد مصباح القاضي. r- العقوبات البديلة المقترحة في دول الخليج العربي: عبد الله بن عبد العزيز السعيد.

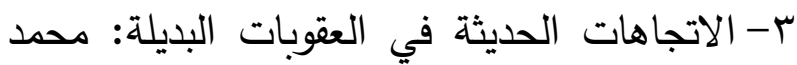

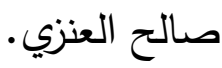
ع-بدائل العقوبات السالبة للحرية وأثرها في الحدي من الخطورة الإجرامية: بشرى رضا راضي سعد.

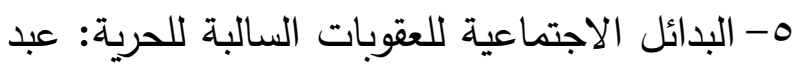
الله اليوسف. ج- العقوبات البديلة للعقوبات السالبة للحرية القصيرة المدة: أسامة الكيلاني. فهذه الدراسات بعضها تتاول البدائل من وجهة نظر

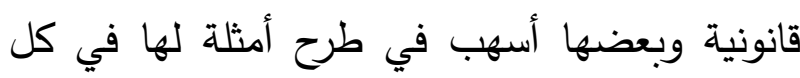

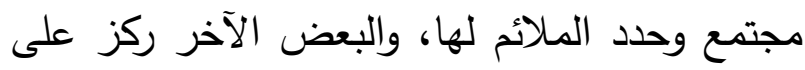
البديلة في قضايا الأحداث. ومنهم من تحدث عن وحن البحن

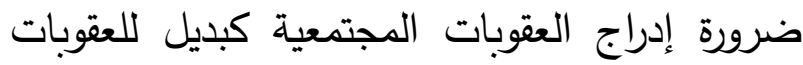

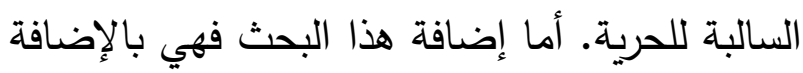


ـ--إن التوقيف في السجن ليس هدفاً بحد ذاته؛ بل هو وسيلة للحد من الجريمة وردع مرتكبها وذلك فئك يتحقق في أي عقوبة بديلة ومن أجل ذلك كله ظهرت عقوبات بديلة للسجن متتوعة. ومن المعلوم أن هذا الموضوع هو من باب التعازير

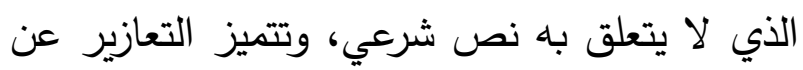

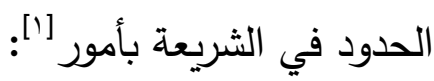

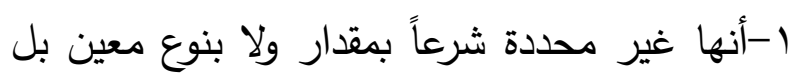
يقدرها بما يحقق المصلحة حسب حجم الجريمة ونوعها وحسب اختلاف الجاني والمجني عليه.

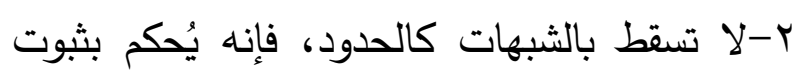
موجبها مع قيام الشبهات [r]. ب-في الحدود والقصاص يجب على الإمام تتفيذها

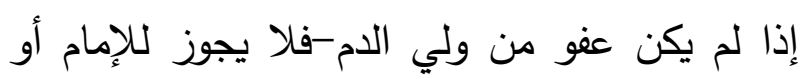

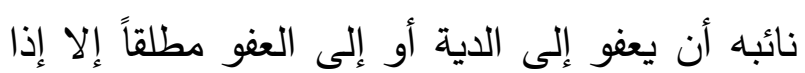

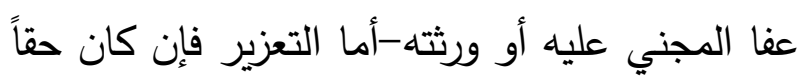
لله تعالى وجب تتفيذه ويجوز العفو والثفاعة إن رُبِئي

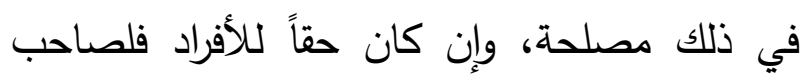
الحق أن يتركه بعفو أو غيره ولو بعد ران رفعها لـإِمام [r] ع-التعزير يسقط بالتوبة بلا خلاف، والحدود لا لامان تسقط بالتوبة على الصحيح إلا الحرابة فإنها تسقط بله

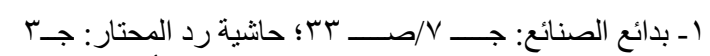

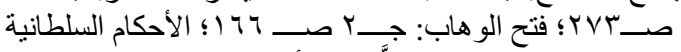

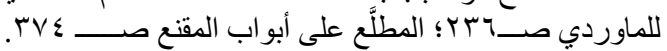

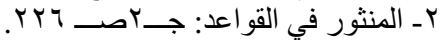

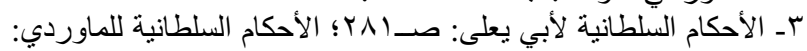
صـ

\section{منهج البحث}

- اعتمدت المنهج التأصيلي والاستقرائي وذلك مانك بالرجوع إلى المصادر الأصلية ما استطعت إلى

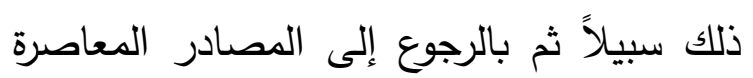

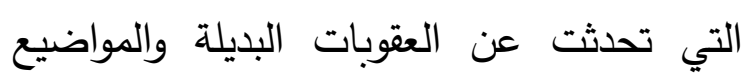

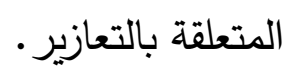
- الحرص على تدعيم البحث بالنصوص الثرعية

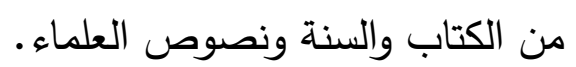

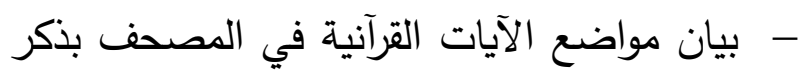
اسم السورة ورقم الآية وتخريج الأحاديث الواردة في ثنايا البحث من كتب الأحاديث والتخريج. المبحث الاول: تأصيل وتكييف العقوبات البديلة المطلب الأول: مفهوم الأحكام البديلة ومدى الحاجة إليها لا شك أن النظام القضائي في الإسلام يأخذ بكل

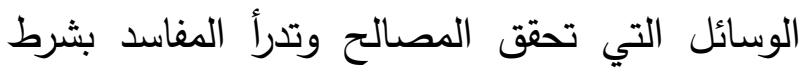
عدم تعارضها مع الثرع ومنها أخذِه بالعقوبات البديلة، والتي يقصد بها في الغالب الأعم عقوبة السجن وهذه تَبين عدم جدواها للآتي: ا-تكاليفها باهظة من عناية ورعاية وتأهيل ومتابعة عندانية

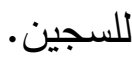
ץ-قد يقتضي الأمر وجود السجين في سجن لذوي جرائم كبيرة مع أن قضيته لا ترتقي لمستوى سجنه.

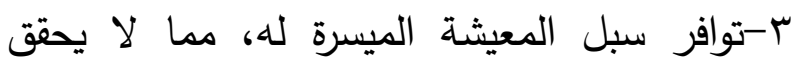

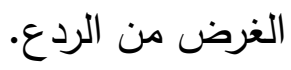


المسألة الأولى: المقصود بالأحكام البديلة وأنواع الجرائم التي تدخل فيها

لم أقف على تعريف علمي وفقهي دقيق للأحكام البديلة؛ ولعل السبب في ذلك عدم الذهاب بتصور المستمع لها بأن هناك عقوبة أصلية أو بديلة وهو ذات الأمر الذي يكمن وراء إطلاق لفظ (بدلائل السجون) عليها. ويمكن تحديد مفهومها بـ: الأحكام الصادرة عن القضاة على جريمة معينة لا يتعلق بها حد شرعي وهي متتوعة منها: عقوبات وإلزامات قضائية وعقوبات تتعق بالخدمة الاجتماعية والتطوعية أو الإقامة الجبرية وغيرها من التكاليف والإلزامات التي تحقق معنى العقوبة والتقويم والإصلاح ولكن بطريقة أكثر تتاسباً وفاعلية في

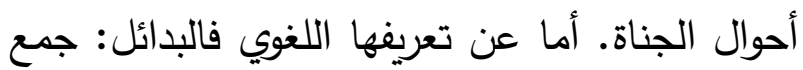

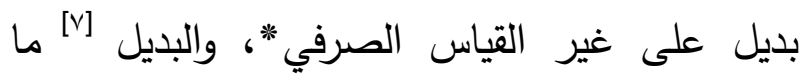
يخلف الشيء ويقوم مقامه، فالبدل لا يخرج عن كونه

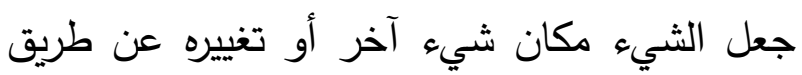
المبادلة، فيقوم مقام المبدل ويسد مسده ويبني حكمه على حكم مبدله. وبما أن هذا المصطلح (بدائل السجن) لم يذكر في كتب الفقهاء فقد حاول البعض

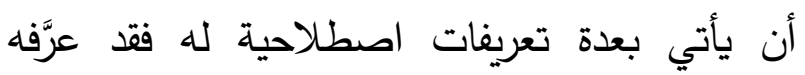
الذيابي [^]: بأنه مجموعة من تعريفات

بديل هو إبدال ولكن رأى الأخذ بجمع بدائل لبديل و إن كان مخالفاً

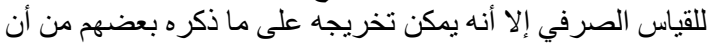

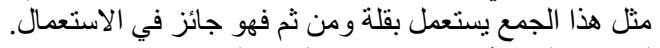

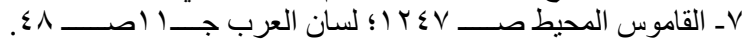
^ـ في رسالة بدائل السجن؛ در اسة مقارنة.

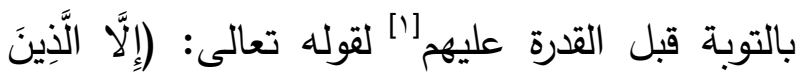

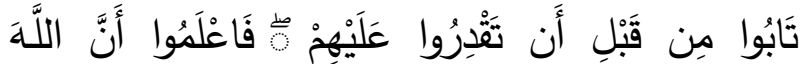

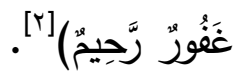
ه-العقوبة التعزيرية يجوز إيقاعها على الصبي وعلى المنون الذي لديه بعض الإدراك؛ لأنه عقوبة تأديبية، وتأديب هؤلاء جائز إذا ثبت اقترافهر لها يستوجب التعزير ، أما العقوبة الحدِّية والقصاص فإنها لا توقَع على أياً من هؤلاء؛ لأن التكليف من أهم الته شروط إقامة الحد [r].

؟-التعزير يختلف باختلاف الناس فتعزير ذوي الهيئات أخف من غيرهم لقول الرسول (أقيلوا

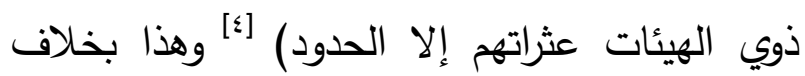
الحدود والقصاص فالناس بها سواء [0]

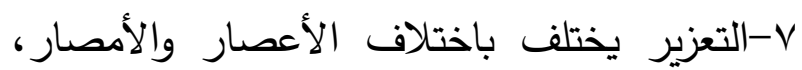

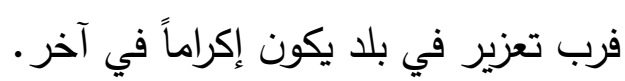

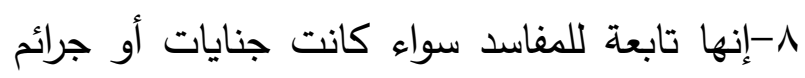
وسواء كانت معاصي أو مجرد مفاسد، أما الددود

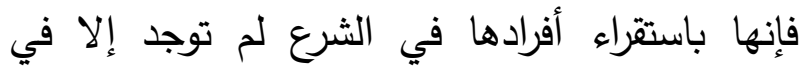

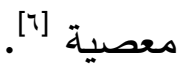

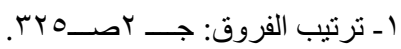

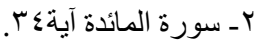

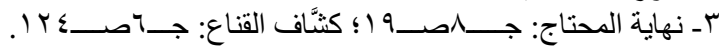

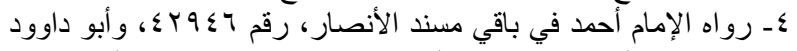

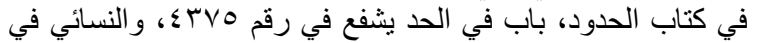

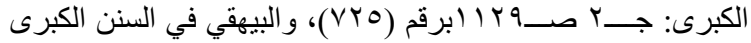

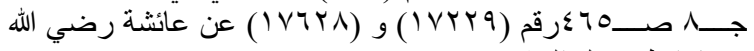

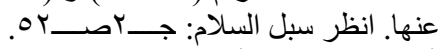

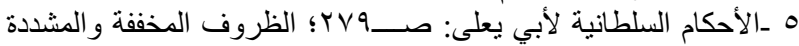

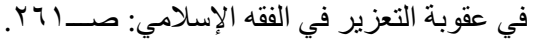

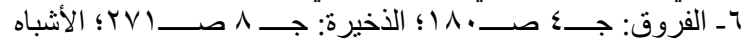

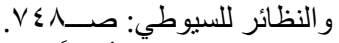

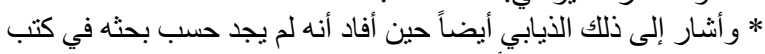

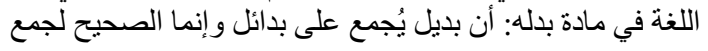


التدابير التي تحل محل السجن لإصلاح الجاني وقد عرَّفه من أعد مشروع [॰] بدائل السجن المقترح وحماية الجماعة أو التثبت من المتهم والكثف عن في وزارة العدل بالمملكة بأنه: مجموعة من التدابير

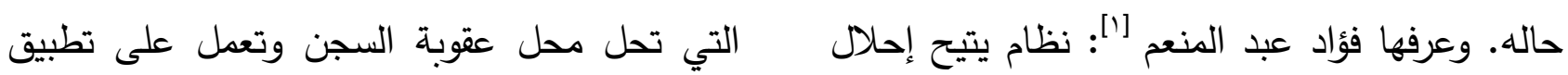
عقوبة من نوع معين محل عقوبة من نوع آخر سياسة منع الجريمة. قضائياً، سواء تم الإحلال ضمن حكم الإدانة أو ويمكن الاتيان بتعريف قريب إلى تعنى تعريفات الفقهاء

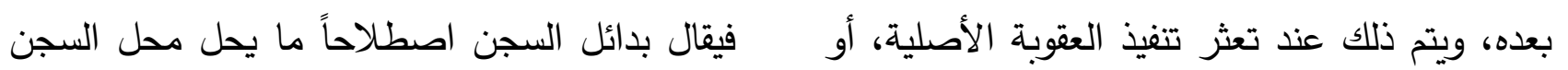

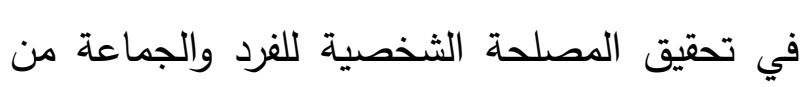
عقوبات التعزير [?]. قيام احتمال تعذّر تتفيذها أو إذا كانت العقوبة البديلة

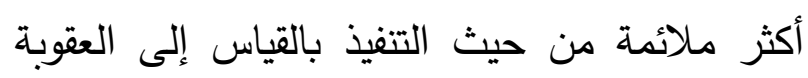
فكل هذه التعاريف وإن اختلفت مصطلحاتها إلا أنها

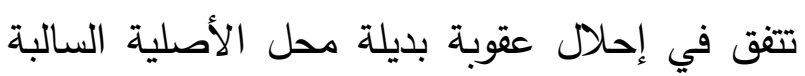

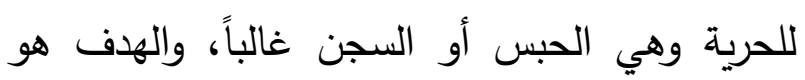
لإصلاح المتهم وزجر الآخرين والحيلولة دون دخول من يحكم عليه بها السجن، فهي إذا تخضع لكافة الحنين

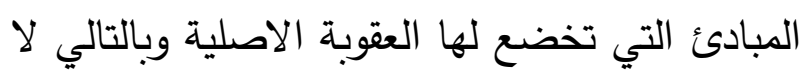
يختلف تعريف العقوبة البديلة عن تعريف الأصلية

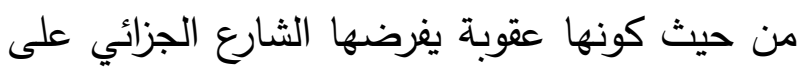

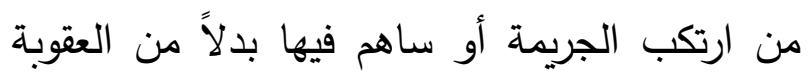
المتمثلة في الحبس.

والجرائم التي تدخل في العقوبات البديلة هي كل جريمة لم يرد فيها حد شرعي مقدر ويعرفها الفقهاء

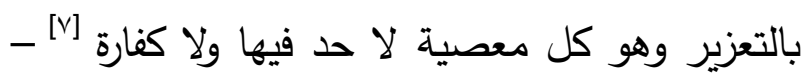
كما أسلفت- كالمعاكسات وأنواع من من التحرش

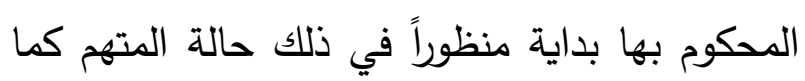

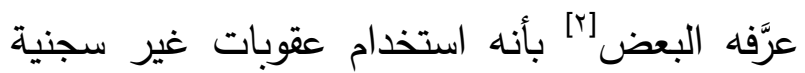
بدلاً من العقوبات البديلة السجينة وهذا يخرج العقوبات المقيدة للحرية من مفهوم الإجراءات البديلة

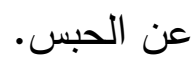
وعُرِف أيضاً [ع] باتخاذ عقوبات غير سجنية ضد المذنبين، فهذا التعريف يحصرها (البدائل) في عقوبة بانية المذنبين وسواء كانت تلك الإجراءات البديلة المتخذة فئن

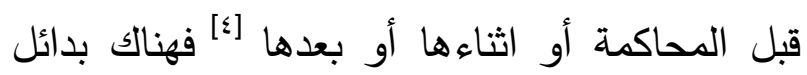
للقبض والتحقيق وبدائل للمحاكمة إلى جانب بدائل إنل لعقوبات صدر الحكم بها، فمجال تطبيق البدائل

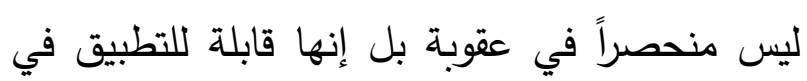
جميع مراحل الدعوة الجنائية.

هـ مسودة مشروع نظام العقوبات البديلة المقتر ح والمرفوع من قبل

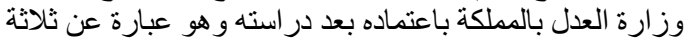

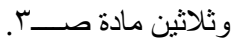
ا ـمفهوم العقوبة و أنو اعها في الأنظمة المقارنة: بحث مقدم في ملتقى التى الاتجاهات الحديثة.

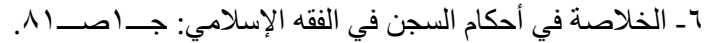

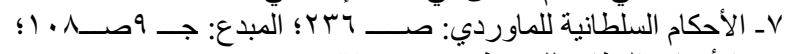

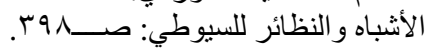


النبي وأمثاله إذا كان فيه مصلحة.

r-إن استعمال السجن كان محدوداً في عهد النبي

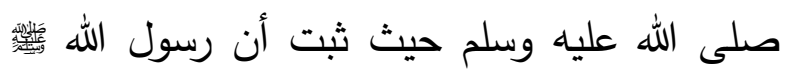
(حبس رجلاُ في تهمة) [r] أما في عهد عمر والخلفاء

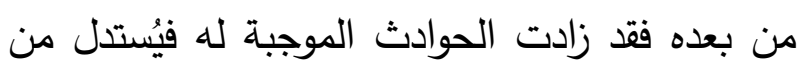
ذلك بأن السجن لم يكن العقوبة الأساسية للجرم المقترف.

ب-القياس على الجزاء لمن ترك أفعال الإسلام الظاهرة كأن يترك قوم الصلاة في الجماعة أو إقامة الجاء

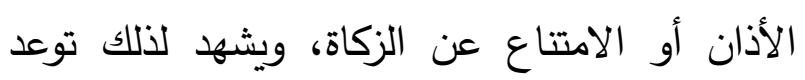

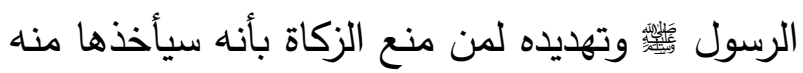

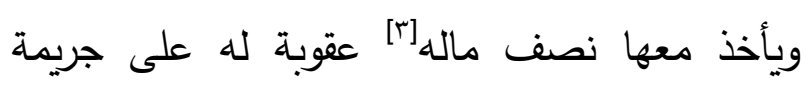

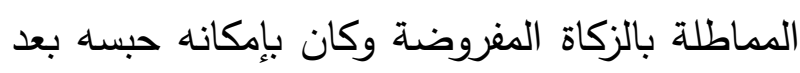
أخذ الزكاة منه، كما عزر

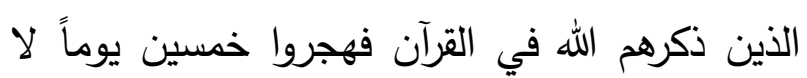

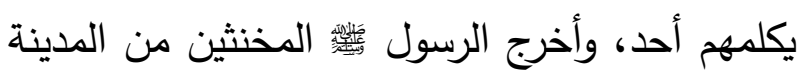
ونفاهم وفعل الصحابة كذلك معهم، وقام عمر بن إنراج

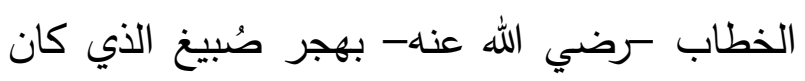
يسأل عن الذاريات وغيرها ويأمر الناس بالتفقه في

rـ أخرجه الترمذي في سننه كتاب الديات باب ما جاء في الحبس في

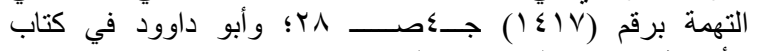

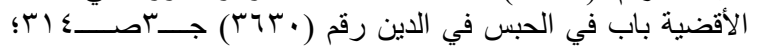

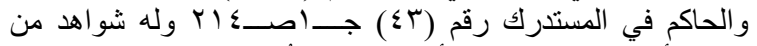

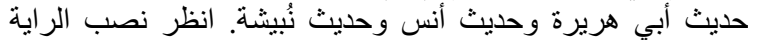

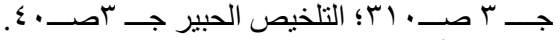

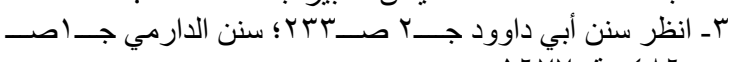

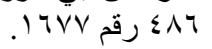

الجنسي والسرقة التي لا قطع فيها لكونها لم تتوفر فيها شروطها. المسألة الثانية: مشروعية تطبيق العقوبات البديلة في الشريعة الإسلامية

لا شك ان السجن ليس عقوبة أصلية في الثريعة الإسلامية حتى نبحث لها عن بديل، إنما العقوبات

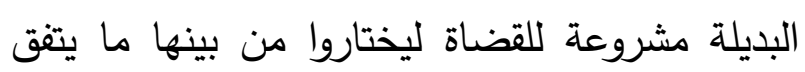
مع مقاصد الثريعة من تطبيق سياسة العقوبات. وليس في تشريعنا الجنائي أيضاً بدائل لأصوله فكل مليقل

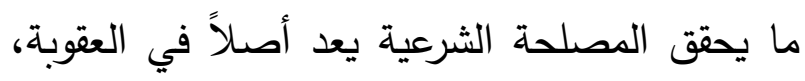

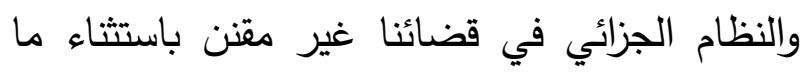

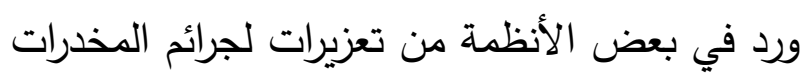
والرشوة والتزوير وغسل الاموال ونحوها فالقضايا التعزيرية واسعة وقابلة للتتوع والتغبير بحسب ولتروير وأحوال الزمن والوقائع. والقول بمشروعية تطبيق العقوبات البديلة في الثريعة الإسلامية يستند إلى أدلة متكاثرة منها:

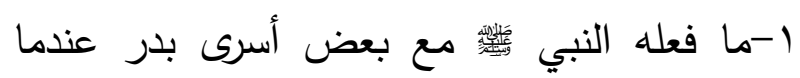

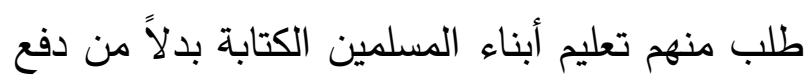
الفذاء المالي ["] فهذا الحديث وإن كان ليس بصريح في الدلالة على المسألة التي نجن بصددها إلا أنه يفيد بأن استبدال العقوبة المالية (وهي مبلغ الفذاء) بعمل يخدم فئة من المجتمع وهو تعليم الكتابة

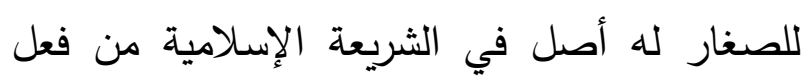


يُضرب، ومنهم من يُحبس، ومنهم من يُقِقم واققاً على قدميه في المحافل، ومنهم من تُنزع عمامته، ومنهم تُهم من يُحل إزاره.

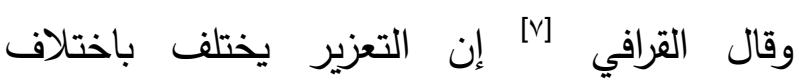
الأعصار والأمصار، فرُبَّ تعزير في بلد يكون بلان إكراماً في بلد آخر كقطع الطيلسان ليس تعزيراً في الثام بل إكرام، وكثف الرأس عند الأندلس ليس

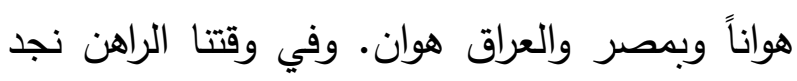

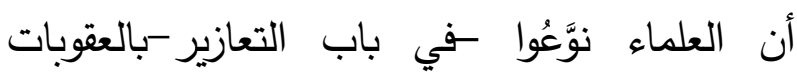
وتوسعوا في أدواتها من التوبيخ إلى ما هو أكبر وبما

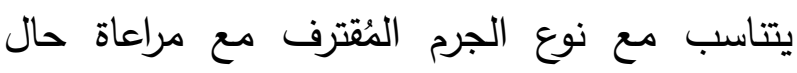

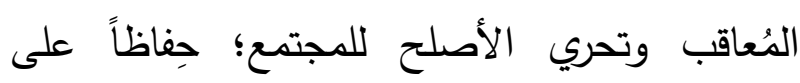
حقوقه ومصالحه.

المطلب الثاني: القواعد والضوابط الفقهية التي تتخرج عليها العقوبات البديلة. هناك عدد من القواعد التي يمكن أن تستند إليها بائل السجن نظراً وتطبيقاً وهي: القاعدة الأولى: كل تصرف لا يترتب عليه مقنيه مقصودة لا يشرع وبيطل إن وقع [^]. التصرف المحكوم عليه في هذه القاعدة يدخل تحته كل تصرف سواء كان تصرفاً مالياً أم تصرفاً غير

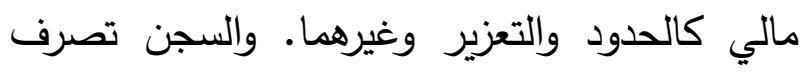
من تصرفات الولاة، وإذا لم يحقق المقصود منه فإنه

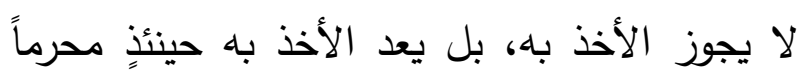

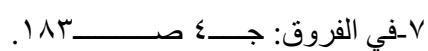

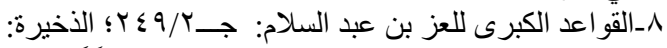

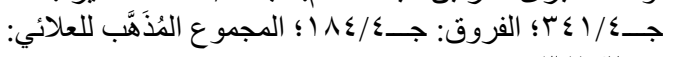
. $r \leqslant \tau / r \rightarrow$
المشكلات من القرآن وضربه ضرباً شديداً ونفاه إلى الى

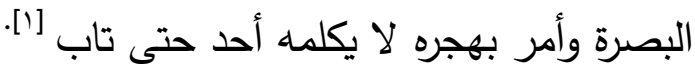
ع -القياس على الكفارات فقد جعل الثارع فيها زواجر بأعمال تعبدية محض كالصوم، والمقصود بالكفارة في الثرع [r] ما يقوم به المذنب من عتق أو صيام أو إطعام لفعله ما يستوجبها. واستعملت الكفارة كعقوبة أصلية في القتل الخطأ، وتأخذ صورة عتق لقان رقبة مؤمنة فإن لم يجد فصيام شهرين متتابعين،

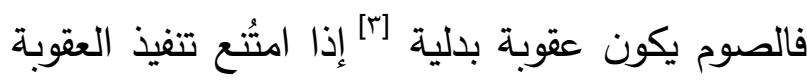

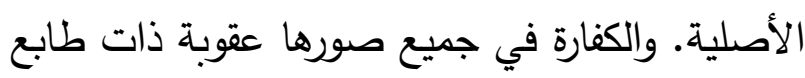
مالي، وقد تكون مصاحبة لعقوبة مقدرة كالدية في التتل الخطأ، وقد تكون مصاحبة لعقوبة غير مقدرة

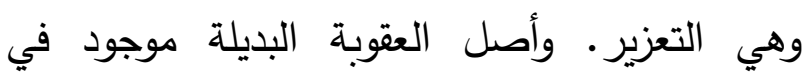
مدونات الفقه الإسلامي كوإن لم يُنكر باللفظ- فقي

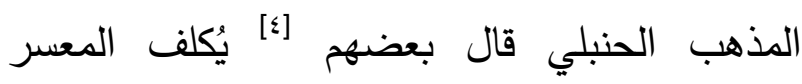
بالعمل حتى يُسدد ما في ذمته. وورد في الأشباه

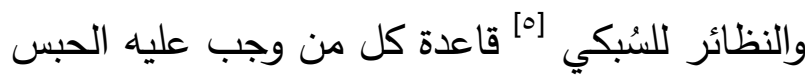

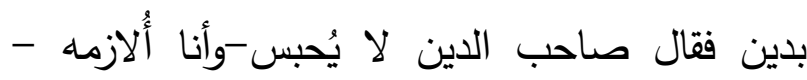

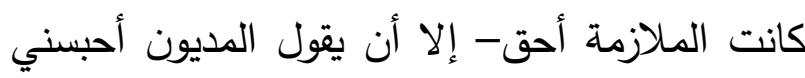

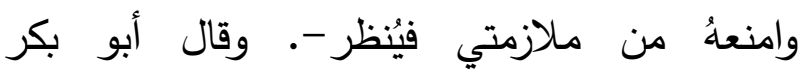
الطرطوسي في أخبار الخلفاء الدتقدمين []"] أنهم كانوا يعاملون الرجل على قدره وقدر جنايته، فمنهم من لئن

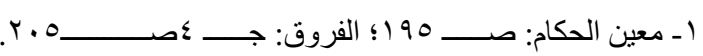

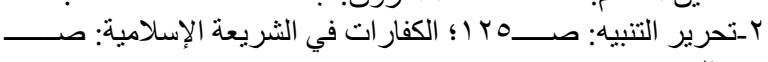

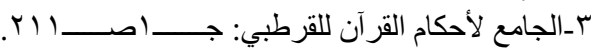

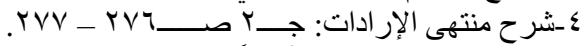

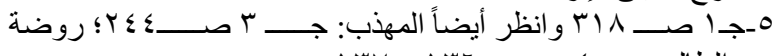

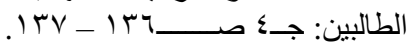
rq1 
يراه القاضي للتوصل إلى معرفة الحق، والأصل منع التعدي والأذى إلا بعد ثبوت الإدانة [؛]. وهذا يدل اللاصل

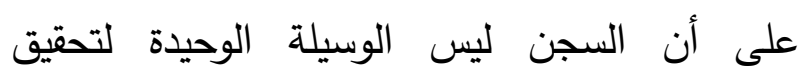

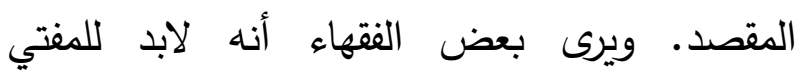

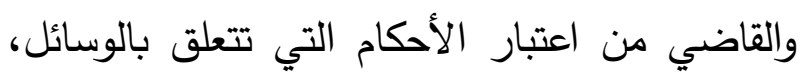

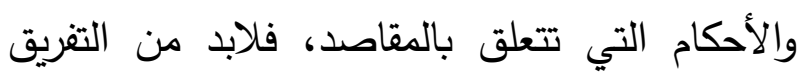

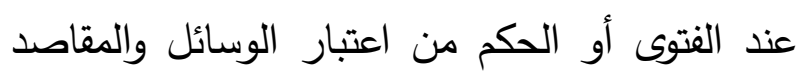

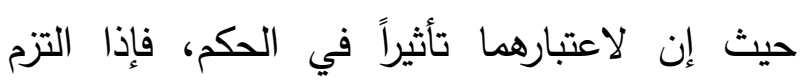
المفتي والقاضي هذه القاعدة أفادتهما كثيراً في التوصل إلى الحق الذي ينبغي بذل الجهد من أجل إصابته [0] المبحث الثاني: الأحكام البديلة، أقسامها وأنواعها، معوقاتها، أمثلتها، الآثار الإيجابية لها. المطلب الأول: أقسام الأحكام البديلة وأنواعها:

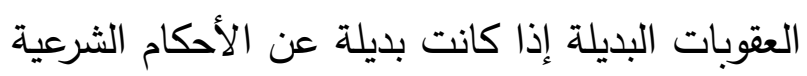

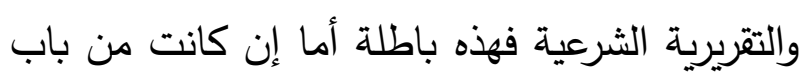
الاجتهادات التعزيرية التي يقوم بها القاضي فلا بأس بأس باتس بها مع ضرورة مراعاة نفسية وعقلية من ستُطبق عليه العقوبة وغيرها من الضوابط السابق ذكرها. والعقوبات البديلة هي عقوبات أصلية قبل أن تكون بديلة، وإنما تُعتبر بديلة لما هو أثد منها إذا أمتتع

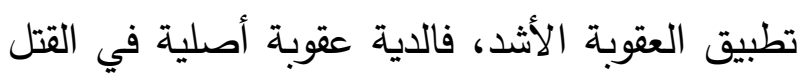

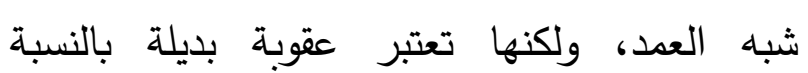
للقصاص ["]، والتعزير عقوبة أصلية في جرائم

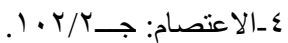

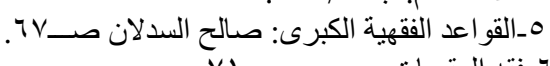

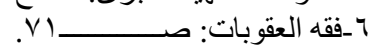

شرعاً. ويترتب على ذلك أن يؤخذ ببدائله. والسجن

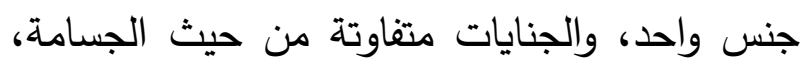
ومن حيث قصد الجاني وعدم قصده، وتكرار الجناية

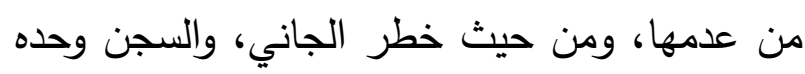

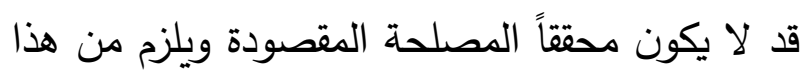
إيجاد بدائل للسجن تحقق المصلحة الثرعية المقصودة من تشريع التعزير [י]. القاعدة الثانية: الأصل ملائمة العقوبات التعزيرية للجنايات [r]. بناءً على هذا الأصل مع ما عُرف من أن السجن لا لا

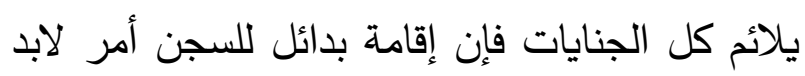
منها. القاعدة الثالثة: مهما حصل التأديب بالأخف من

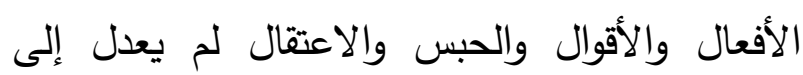

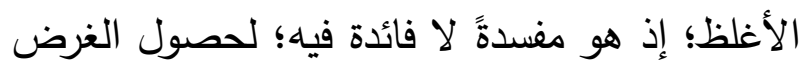
بما دونه ["] هذا الضابط الذي نص عليه العز بن عبد السلام واضح الدلالة على المراد إذ كل فرد من أفراد التعزير ومنها السجن إذا كان غيره أقوم بالمصلحة منه فإنه لا يعدل إلى الأشد الأغلظ. القاعدة الرابعة: يُغتنفر في الوسائل مالا يُغتفر في المقاصد. ومعناها أن حكم الوسيلة إلى الثيء يختلف عن حكم غايته ومقصوده ومثالها: جواز تعزير المتهج بما 
امتتع من دفع الدين ونحن نعرف ماله أخذنا منه مقدار الدين ولا يجوز لنا حبسه، وكذلك إذا ظفرنا بماله أو داره أو شيء يُباع له في الدين كان رهناً أم لمان لا فعلنا ذلك، ولا نحبسه؛ لأن في حبسه استمرار ظلمه ودوام المنكر في الظلم وضرره هو مع إمكان ألا يبقى شيء من ذلك كله. ومن ناحية أخرى يُقسم البديل إلى قسمين، بديل عن أصل السجن وبديل عن بعض المدة المقررة. وبالنظر إلى نسبتها إلى السجن في الثدة والضعف تتقسم إلى بدائل أشد من بن إندان السجون وبدائل أخف منه. وبالنظر إلى نوع البديل تُقسم إلى بديل مالي وبديل غير مالي وبديل حسي

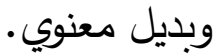

وتُصنف على حسب المراحل التي تمر بها القضية

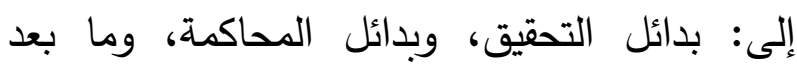
صدور الحكم والتتفيذ. وتُصنف حسب نوبن نوع الجريمة: بدائل لجرائم المخدرات، وبدائل لجرائم الأخلاقيات، ولئ

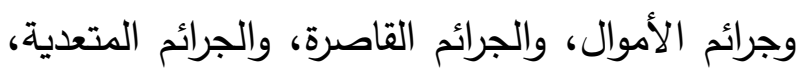
والمخالفات، والجنح البسيطة، والجرائم الخطيرة. وبحسب معيار وطبيعة التدبير المُتخذ ومحله تُصنف إلى مالية وبدنية ومعنوية. وإذا تقرر بأن العقوبات البديلة هي عقوبات تعزئية وليهية،

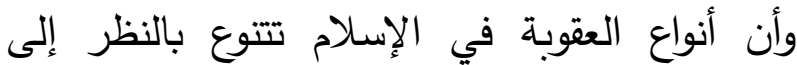

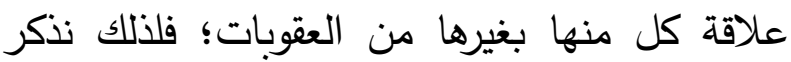

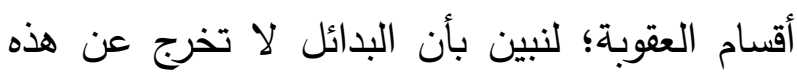

التعازير ['] ولكن يُحكم به بدلاً من القصاص أو الحد إذا امتنعا لسبب شرعي. والعقوبات البديلة يمكن

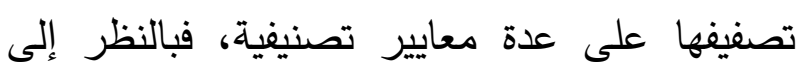
تعينها وعدم تعينها يمكن أن تُقسم إلى ثلاثة أقسام: ا-ما يتعين في البديل؛ لعدم تحقيق الحبس

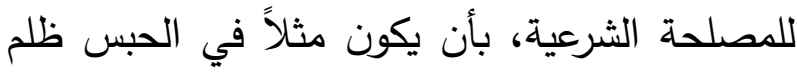

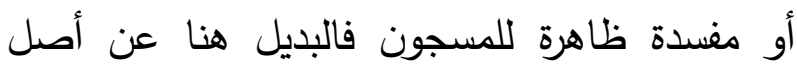

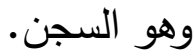
Y-ما يتعين فيه الحبس لعدم تحقيق البديل للدصلحة الشرعية؛ وذلك إذا كان السجن هو الوحيد بين أفراد التعزير الذي يُحقق المقصود، سواء حماية المجتمع أو إصلاح الجاني أو حفظ الحقوق. ب-ما لا يتعين فيه أحدهما، بل يختار ولي الأمر ما ها يراه راجحاً من أفراد العقوبات التعزيرية وقد أشار

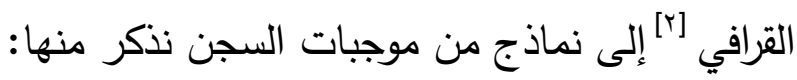

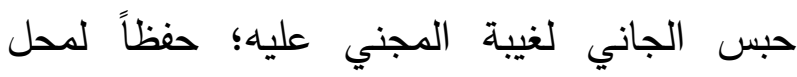
القصاص وحبس الممتنع عن دفع الحق وحبس الجاني تعزيراً وردعاً عن معاصي الله، وحبس الممتنع في حق الله الذي لا تدخله النيابة كالصوم عند الثافعية، وحبس من أقر بمجهول عين أو لو لأه بشيء في الذمة وامتتع من تعيينه فيجب حتى

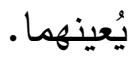
ثم أثار إلى ما تتعين فيه البدائل قائلاً [" ولا يجوز الحبس في الحق إذا تمكن الحاكم من استيفائه، فإن

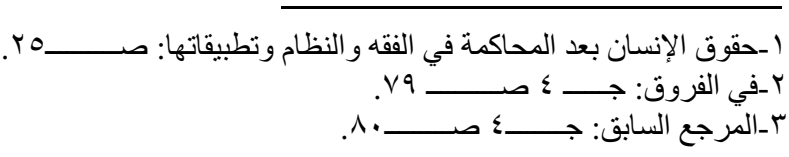


ع-عقوبة تكميلية: وهي عقوبة تتبع العقوبة الأصلية، فتصيب الجاني بناءً على الحكم بالعقوبة الأصلية، ولكن بشرط أن يحكم بالعقوبة التكميلية. والعقوبات التكميلية تتفق مع التبعية في أن كليهما مترتبة على حكم أصلي، ولكنهما يختلفان في أن العقوبة التبعية تقع دون إصدار حكم خاص بها، أما التكميلية فتستوجب صدور حكم بها، ومثل العقوبة التكميلية تعليق يد السارق في رقبته [0] بعد قطعها حتى يطلق سراحه، فإن تعليق يذ السارق مترتب على القطع ولكنه لا يجوز إلا إذا حكم به. ومنها تغريب الزاني غير المحصن. وتنقسم العقوبات من حيث سلطة القاضي في تقديرها إلىى:

ا-عقوبات ذات حد واحد: وهي التي لا يستطيع القاضي أن ينقص منها أو يزيد فيها ولو كانت تقبل بطبيعتها الزيادة والنقصان كالتوبيخ والنصح وكالجلد المقرر شرعاً. ץ-عقوبات ذات حدين: وهي التي لها حد أدنى وحد أعلى ويترك للقاضي أن يختار من بينها القدر الذي يراه ملائماً كالحبس والجلد في التعازير • وتتقسم من حيث وجوب الحكم بها [] إلى: ا-عقوبات مقدرة: وهي التي عين الشارع نوعها وحدد مقدارها وأوجب على القاضي أن يوقعها دون
فالعقوبة تتقسم بحسب ذاتيتها أو الرابطة القائمة بينها إلى [']: 1-عقوبة أصلية: وهي العقوبات المقررة أصلاً للجريمة كالقصاص للقتل، والرجم للزنا، والقطع للسرقة. r-عقوبة بديلة: سبق تعريفها بأنها عقوبة تحل محل أصلية إذا ما أمتتع تطبيق العقوبة لسبب شرعي ومثلها الدية إذا دُرأ القصاص عن القاتل عمداً أو عفا وليّ المجني عليه عن القصاص ورضي بالدية [ז] وكالتعزير إذا دُرأ الحد أو القصاص. ب-عقوبة تبعية: وهي العقوبة التي لا تتقرر إلا مع العقوبة الأصلية، فلا يمكن تطبيقها إذا لم توجد عقوبة أصلية، فتصيب الجاني بناءً على الحكم بالعقوبة الأصلية ودون حاجة للحكم العقوبة التبعية. ومثلها حرمان القاتل من الميراث، فالحرمان يترتب على الحكم على القاتل بعقوبة القتل ولا يُشترط فيه صدور الحكم بالحرمان [r] وكعدم أهلية القاذف للشهادة، فعدم الأهلية لا يُشترط أن يصدر به الحكم وإنما يكفي لانعدامها صدور الحكم بعقوبة القذف [؛] ومثالها أيضاً الحرمان من بعض الحقوق والمزايا كتولي بعض الوظائف والخدمات العامة التي لها علاقة بالجريمة المرتكبة، وحرمان المحكوم من حمل

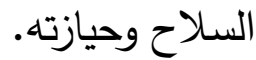

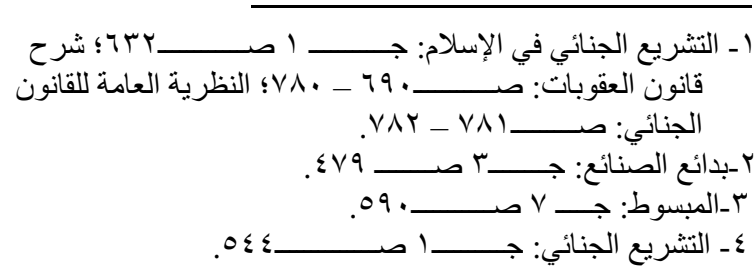


ץ-عقوبات مركبة منهما: كجلد السارق من غير حرز مع إضعاف الغرم عليه. ع-عقوبات سالبة للحرية أو مقيدة لها: مثل السجن والتغريب.

ه-عقوبات نفسية: وهي التي تقع على نفس الإنسان دون جسمه كالنصح والتوبيخ والتهديد واللوم.

المطلب الثاني: معوقات تفعيل البدائل هناك معوقات تسهم بشكل مباشر في تعثر الأحكام

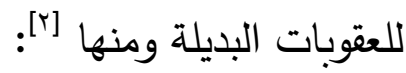
- عدم وجود أنظمة وضوابط وآلية واضحة ومتكاملة للعقوبات البديلة تضبط مجالات تطبيقها وتحدد أسبابها ووسائلها وعقوباتها وتضمن طرق تتفيذها؛ ليسترشد القضاة بذلك وبالتالي يتعذر تتفيذ بعض العقوبات البديلة لانعدام هذه اللوائح التنفيذية المرشدة

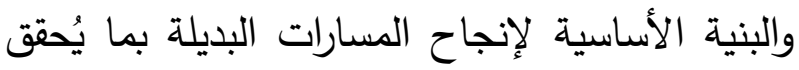
المقصود منها؛ إذ ليس الهدف هو مجرد الحكم بها وإنما الهدف تحقيق الغاية من تطبيقها؛ ولعل من أسباب غياب آلية التتفيذ هو طبيعة هذه البدائل وكونها تحتاج لكوادر متخصصة في التطبيق ذات تأهيل خاص في الجوانب النفسية والاجتماعية لا لا لهات تتوفر عند من يباشر التنفيذ حالياً. - العقوبات البديلة لا يمكن أن تكون صالحة لكل لكل

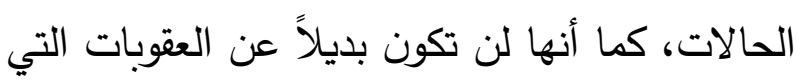
يُوقعها القاضي على المدانين في الجرائم الكبيرة.

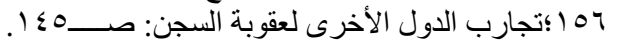

أن ينقص منها أو يزيد فيها أو يستبدل بها مثل

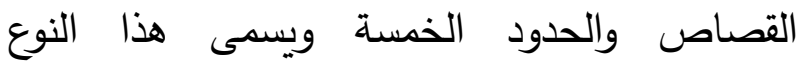
بالعقوبات اللازمة؛ لأن ولي الأمر ليس لله إسقاطها ولا العفو عنها. r-عقوبات غير مقدرة: وهي التعزيرات التي لم يحدد

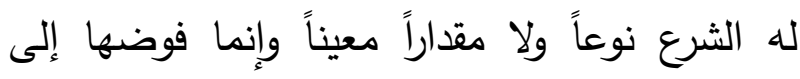
تقدير الحكام لتطبيق ما يرونه محققاً للدصلحة بحسب ظروف الجريمة وحال المجرم ودوافعه وبواعثه. وتسمى بالعقوبات المخيرة؛ لأن للقاضي أن

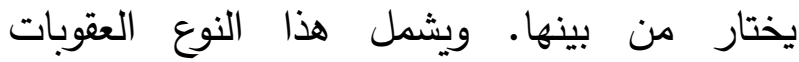
المشروعة على كل معصية أو منكر أو إيذاء لأحد

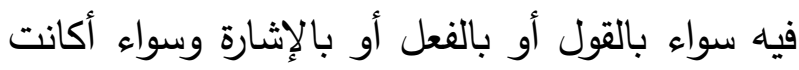

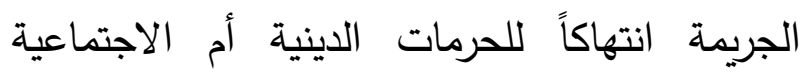
كالأكل في نهار رمضان بغير عذر، وترك الصلاة

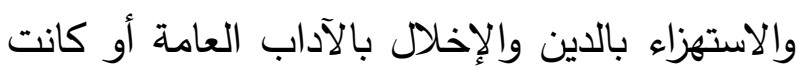
اعتداء على حق شخصي. وتتقسم من حيث محلها ['] أو متعلقاتها إلى : ألى 1-عقوبات بدنية: وهي العقوبات التي تقع على جسم الإنسان كالقتل والجلد والحبس والرجم. والجرائم الموجبة للعقوبات البدنية ثلاث عشرة جريمة: القتل والجرح والزنا والقذف والخمر والسرقة والبغي والحرابة

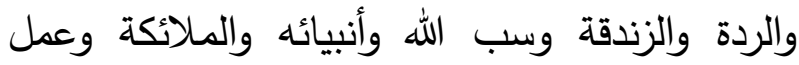
السحر وترك الصلاة والصيام. r-عقوبات مالية: وهي التي تصيب مال الثخص ولئرس كالدية والغرامة والمصادرة والإتلاف. 1 ـالجر ائم الجنائية وعقو باتها الدقدرة في التشريع الجنائي الإسلامي: 
- الخلاف حول من يتولى تتفيذ العقوبات البديلة التي لا تتضمن سجناً كخدمة المجتمع؛ حيث نجد أن المتبع في كثير من الدول أن وزارة الثؤون الاجتماعية وهي جهة مدنية هي التي تتولى التنفيذ، وهناك اختلاف في طريقة التنفيذ من جهة إلى أخرى مما يجعل القضاة في شك من ذلك ومن ثم يتوجهون

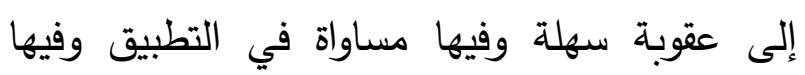
انتقام. - البدائل تستلزم إشراك جهات غير قضائية ولا أمنية كوزارة الثؤون الاجتماعية في التنفيذ. - غياب الإشراف القضائي على تنفيذ العقوبات،

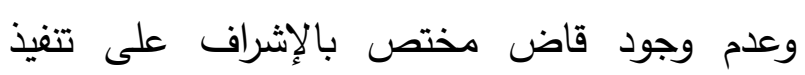
العقوبات أدى إلى عدم الثقة بجدوى الحكم بهذه بالئن البدائل.

- إن الأنظمة الموجودة كأنظمة مكافحة الغش التجاري والرشوة والتزوير ونظام المرور ونظام مكافحة المخدرات وغيرها لم تدرج هذا النوع من ونط البدائل بالثكل الكافي. - بعض الجهات الحكومية تساهم بشكل غير مباشر بأن

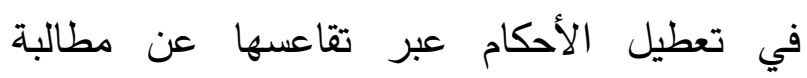
منسوبيها بالمثول أمام الجهات التنفيذية التي تطلب استدعائهم وحضورهم، فضلاً عن التراخي في تفعيل البرنامج الإكتروني لمتابعة تتفيذ الأحكام.

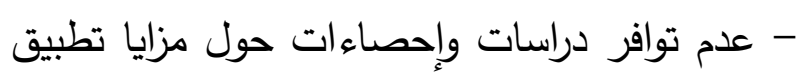
هذا المفهوم، وهذا راجع لضعف الإمكانات البشرية

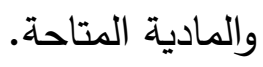

- عدم تقبل المجتمع لهذا النوع من العقوبات؛ لاعتقاد البعض بأنها تنطوي على نوع من التساهل

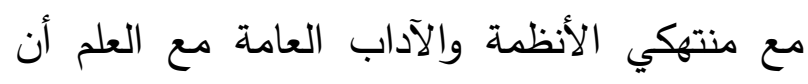

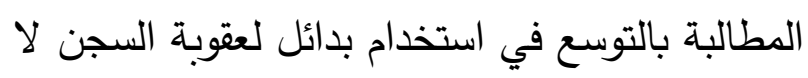

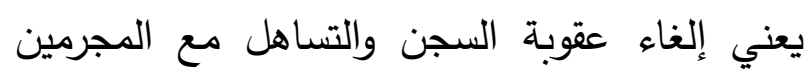

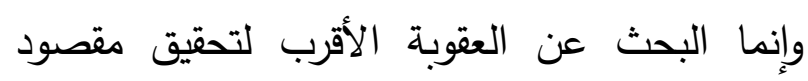
الثارع من تشريع العقوبات. -العقوبات البديلة -إذا كانت عبارة عن عقوبات مالية-قد تشجع الثخص على تكرار فعلته، لاسيما إذا لم تكن لديه مشكلة في دفع المال وخير مثال

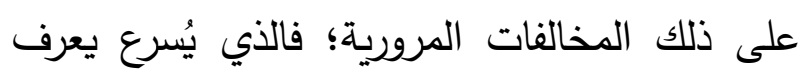
عقوبة سرعته المالية مع ذلك قد يكرر الدفع عشرات المرات. -قد يخضع هذا النظام في حال تطبيقه للواسطة -

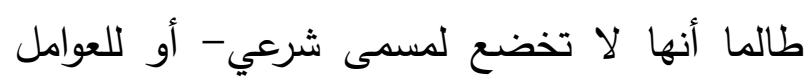
الثخصية (الميل، المال، الغضب....).

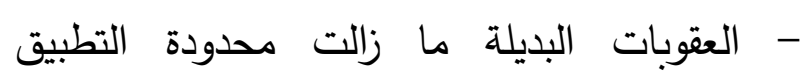
والموجود منها يمثل حالات اجتهاد، على الرغم من أهميتها الشرعية القضائية الواضحة والحاجة القائمة للعمل بها؛ لذلك لابد من تفعيل هذه العقوبات لتخرج

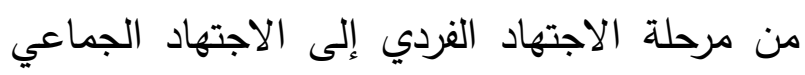

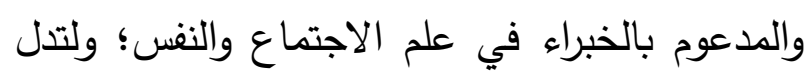

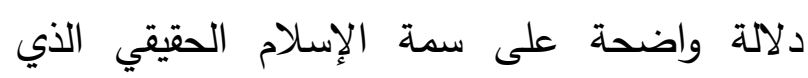

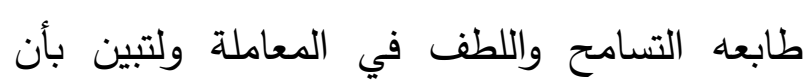
البديلة ليس فيها تمييع للأحكام والعقوبات، وإنما هدفها التهذيب والإصلاح الجماعي. 
1-المراقبة القضائية: وهي إجراء قضائي تتخذه المحكمة بحق المجرم بعد إدانته نهائياً عن جريمة ما. حيث تأمر المحكمة بإطلاق سراحه تحت شروط تحددها هي وبإشراف ومراقبة شخصية من قبل هيئة أو إدارة المراقبة القضائية المختصة، وهي نوع من المعاملة الإصلاحية تهدف إلى إعادة بناء شخصية

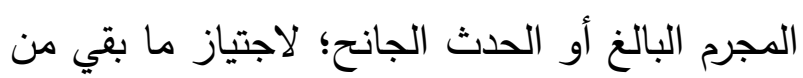
مدة حكمه بسلوك حسن خارج المؤسسة العقابية ومساعدته على تعديل مسيرة حياته. أما الحكم المعلق فهو تعليق إصدار الحكم النهائي في القضية بهدف الرأفة بالمجرم وتخفيف العقاب عنه [1]. ץ-الإلزام بالعمل لمصلحة المجتمع [r]: وهو إلزام المحكوم عليه بالعمل مقابل قليل من المال يسد حاجته وأسرته؛ خدمة للصالح العام في إحدى المؤسسات العامة أو المشروعات سواء كانت زراعية أم صناعية أو خدمية أو الجمعيات أو غيرها عدداً من الساعات خلال مدة معينة تحدد ف بالحكم، وقد يخصص جزء من أجر العمل الإلزامي لتعويض مل مله المجني عليه. فهذه العقوبات الخدمية والتطوعية يقدرها القاضي محاولاً في الوقت نفسه رفع معنويات السجين بنوعية هذه البدائل. وهناك عقوبات إصلاحية مثل إلزامه بدخول دورات ومحاضرات تأهيلية وتثقيفية تهدف إلى تعديل السلوك وزرع الخير في المذنب بهدف إصلاحه. ومنها عقوبات علاجية كالزامه بدخول المستشفى للعلاج مثل

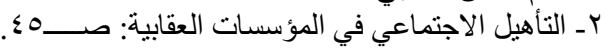

- إن استراتيجية البدائل طُبقت بطريقة كانت تعطي

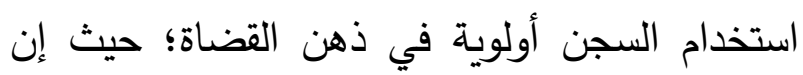
العقوبات الأخرى (البديلة لعقوبة السجن) كان يُنظر لهن

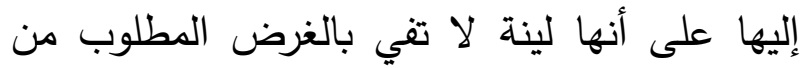

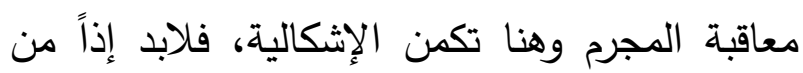
العمل على تغيير موقف القضاة من قضية الحكم بالسجن للتخفيف من مأساة السجون. - الاختلاف في البنية التنظيمية لكل من السجون

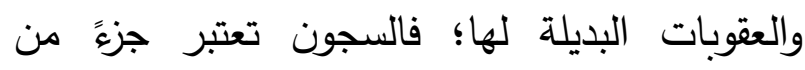
النظام الجنائي الرسمي وتعمل وفقاً لضوابط وقوانين

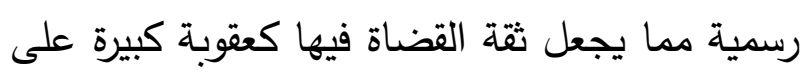
عكس بعض العقوبات البديلة التي لا تتضمن عقوبة

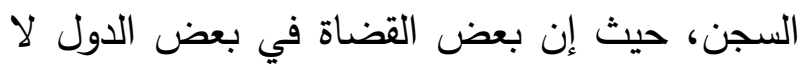
يثقون بها ولا يريدون التعامل معها. - الغموض وعدم الوضوح الذي قُدمت به به العقوبات

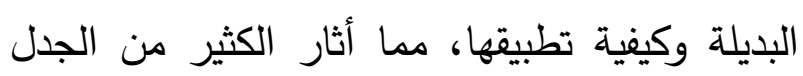
والنقاش وسوء الفهم حيال استخدامها، وجعل إصدار حكم بثلاثة أشهر إلى ستة أشهر أسهل وأكثر قبولاً لاى العديد من القضاة إضافة إلى هذا فإن الحكم التعزيري في القضاء وخاصة في البدائل عادة ما لكادي يكون فيه تباين اجتهادي بين القضاة. المطلب الثالث: العلاج لمعوقات تفعيل البدائل. الأصل في العقوبات البديلة عدم حصرها؛ نظراً لتبعيتها لاجتهاد بعض القضاة وارتباطها بتحقيق

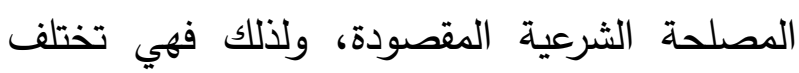
باختلاف الأشخاص والجرائم والمجتمع. 
المنازعة أو انتهائها إما صلحاً وإما قضاءً أو بمضي المدة المحددة في أمر المنع دون صدور أمر أمران بتجديدها أو بصدور أمر لإلغاء المنع من السلطة

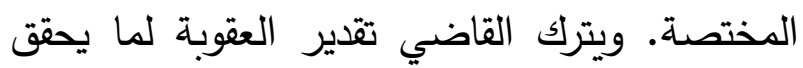
المصلحة الثرعية [؛] - أو سحب رخصة لفئة القيادة، وذكر أهل العلم أمثلة للحرمان تتدرج تحت قاعدة من تعجل شيئًا قبل أوانه عوقب بحرمانه وذكروا منها حرمان القاتل من الإرث، ومسألتنا مندرجة ضمن

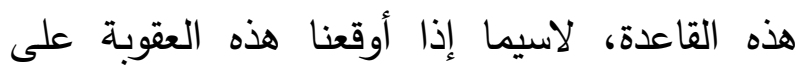

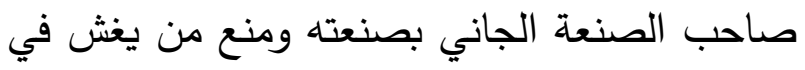

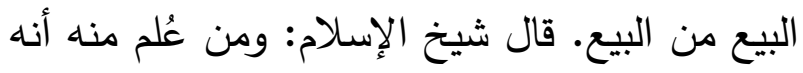
يغبنهم فإنه يستحق العقوبة، بل يُمنع من الجلوس في سوق المسلمين حتى يلتزم طاعة الله ورسوله [॰] צ- العزل: ومعناه حرمان الشخص من وظيفته

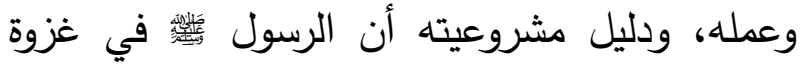

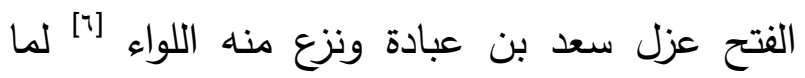
قال: اليوم يوم الملحة اليوم تستحل الكعبة، والحديث

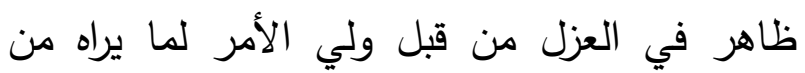
مصلحة في حق من أخطأ. •-العقوبة المالية: وقد قال بالتعزير بالمال الجمهور

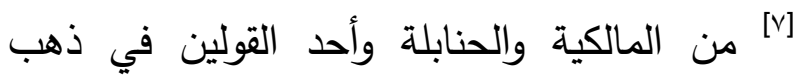

ع ـ مرشد إجر اءات الحقوق الخاصة: وزارة الداخلية جــا الرياض ه

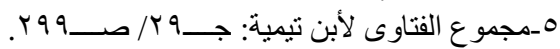

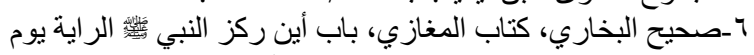

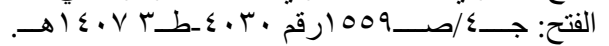

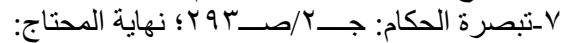

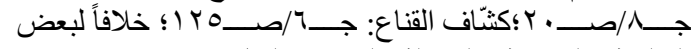

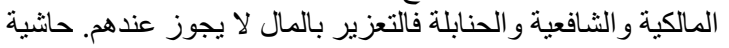

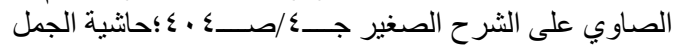

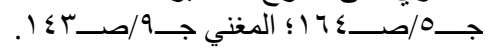

مدمني المخدرات أو المرضى النفسيين الذين بسبب

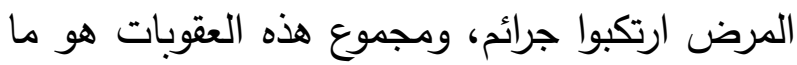
يسىى بنظام تحويل الدعوة الجنائية إلى الطريق الغير جنائي وهو أسلوب حديث يسمح بتفادي الحبس في أحوال معينة بالنسبة للمحكوم عليهم. ويطبق هذا النظام بصورة كبيرة في أمريكا لمتابعة

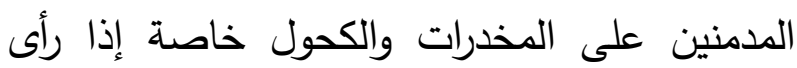
القاضي أن الطريق الجنائي لن يجدي نفعاً. وهناك نوع أخر من البدائل وهو تخفيف العقوبة في مدة لهن السجن لحين التزامه بالسلوك والأخلاق والصلاة داخل السجن أو المشاركة في تدريب السجناء في المهن التي يتقنونها أو المساهمة في تتظيم أعمال

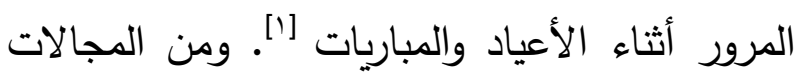
المقترحة في مجال العمل لمصلحة المجتمع: المشاركة في أعمال يدوية أو مهنية مثل نظافة المساجد والاهتمام بها ولاسيما في رمضان وخدمة الصائمين في مشروع تفطير الصائم أو المساهمة في تتظيم ومراقبة الأسواق التجارية والمسالخ في الأيام المزدحمة كشهر رمضان أو إجازتي العيدين

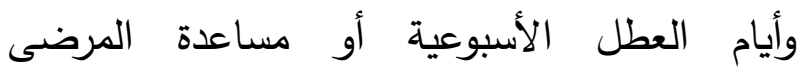
والمعوقين ومن فيحكمهم لمدة معينة [r]

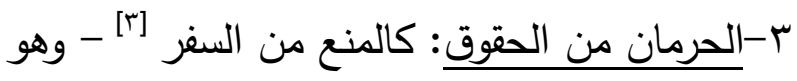
إجراء تحفظي يقصد به منع الشخص بأمر من من من من السلطة المختصة من مغادرة البلاد لحين البت في لهراء

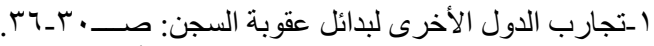

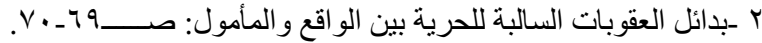

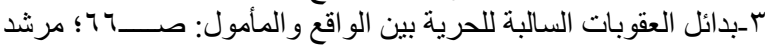

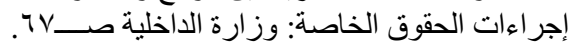




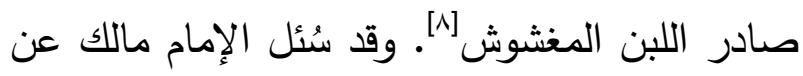

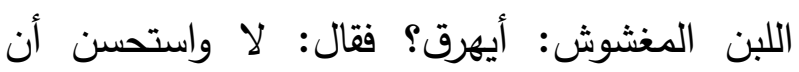
يُتصدق به على من غشه [9].

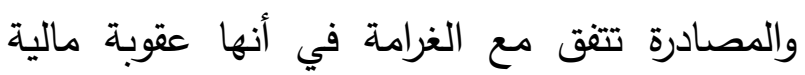
ولكنها تختلف عنها في أن موضوعها الأشياء أو أوناء

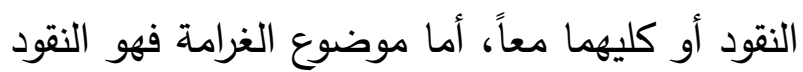
دائماً. 7-التشهير: وهو الإعلان عن جريمة المحكوم عليه، قال ابن فرحون: ويجوز تجريد المعزر من ثيابه إلا جالا ما يستر عورته واشهاره في الناس والنداء عليه بذنبه عند تكرره منه، وعدم إقلاعه عنه، ويجوز حلق شعره

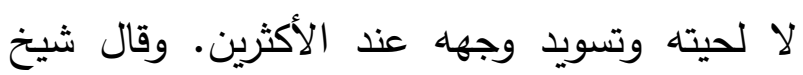
الإسلام ابن تيميه: وقد يعزر بالرجل بوعظه وتوبيخه والإغلاظ عليه بتسويد وجها وإركابه على دابة مقلوباً

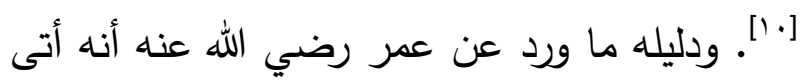

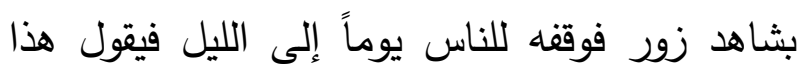

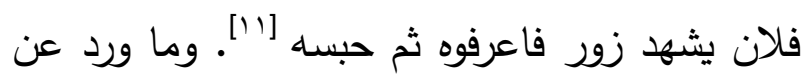

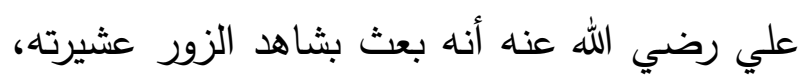
فيقال أنه شاهد زور فاعرفوه [r']. ويُستدل له أيضاً

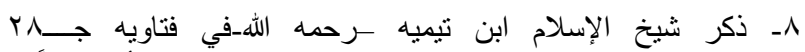

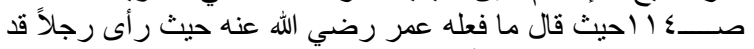
شاب اللبن بالماء المبيع فأر اقه عليه، وهذا رذا ثابت عن عمر بن الخطاب رضي الله عنه.

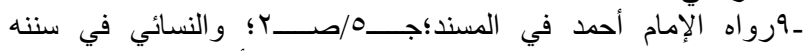

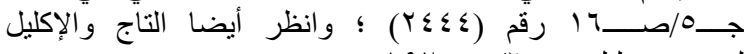

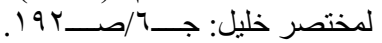

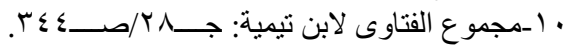

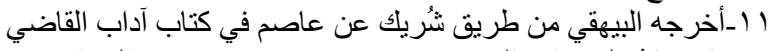

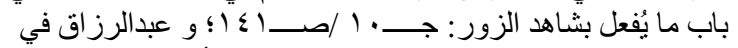

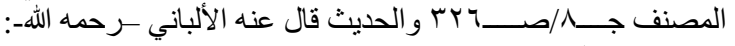

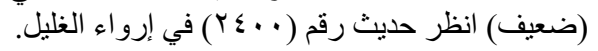

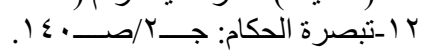

الشافعية وقول أبي يوسف من الحنفية وإليه ذهب

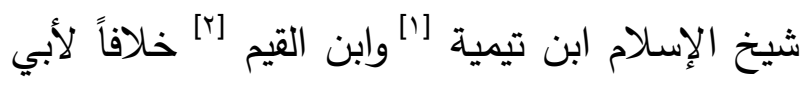

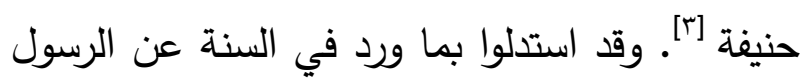

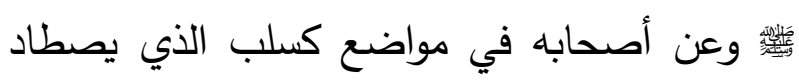

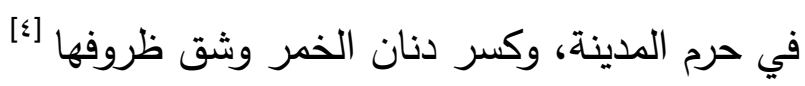
وأمره عبد الله بن عمر بتعريف الثوبين المعصفرين وكسن دنان الثرن فروفين وهدم مسجد الضرار [0] ومضاعفة الغرامة على كاتم

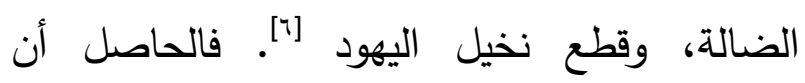
العقوبات المالية اثثتان: الغرامة والمصادرة، فالغرامة عقوبة مالية تُُرض على المحكوم عليه ويُلزم بموجبها دفع مال يُقدره القاضي في قرار الحكم إلى على حزينة الدولة، والغرامة إما أن تكون عقوبة أصلية كما في الجنح والمخالفات أو عقوبة إضافية كما في الجنايات. أما عقوبة المصادرة فهي عقوبة مالية تنزع بموجبها ملكية الثيء المحكوم عليه -الناتج عن عن عندايه الجريمة أو المستعمل فيها نقداً أو عيناً من مالكه -

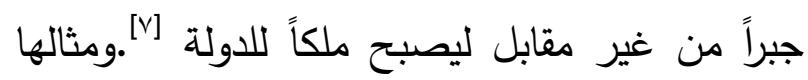
ما ورد عن عمر بن الخطاب رضي الله عنه أنه

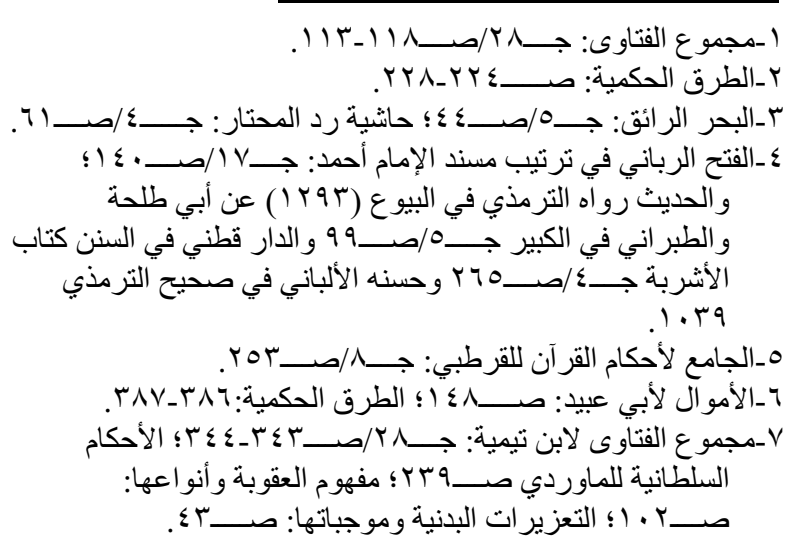


غيره ويُلزم المذنب بعدم الخروج منه إلا لحاجة ضرورية تستوجب خروجه كالعلاج مثلاً؛ وذلك بوضع حلقة في أي جزء من جسمه تعطي مركز الشرطة إشعاراً بخروجه. وهذه الإقامة لا تتم إلا عن طريق الرقابة الإكترونية المكلمة لها من خلال أجهزة استشعار عبر الأقمار الصناعية وذلك بجعل سوار بيد المحكوم عليه أو كاحله (نظام التعقب)

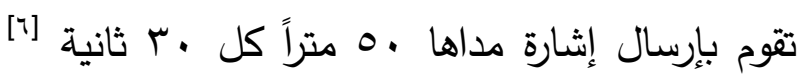
وهذه التقنيات بالإمكان تطبيقها إما عن طريق شبكة الأقمار السابق ذكرها أو عن طريق شبكة الجوال، ولشركة (جوجل) تطبيقات متطورة شبيهة بما سبق مثل (Google latitude) وهذه التقنية توفر الوصول للأهداف بتكلفة مقبولة ومفيدة جداً مع الأحداث لمعاقبتهم. قال الكاساني في تعرف الحبس: هو منع الشخص من الخروج إلى أشغاله ومهماته الدينية والدنيوية مثل الجمع والأعياد وتثييع الجنائز وعيادة المرضى [V]. .ومما يُذكر أصلاً لمشروعية الإقامة قوله تعالى: (فَأَمْسِكُوهُنَّ فِي الْبيُوتِّ) [^] وكذا يُستدل بعموم ما ورد من أدلة السجن؛ إذ الإقامة الجبرية فيها تعويق للجاني، وعليه هي نوع من أنواع السجن قال ابن تيمية: إذا لم يمكن النفي والحبس عن جميع الناس كان النفي والحبس حسب القدرة مثل أن

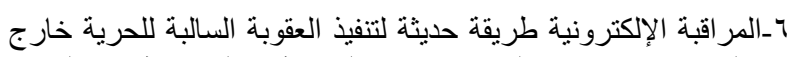

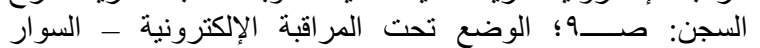

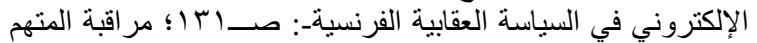

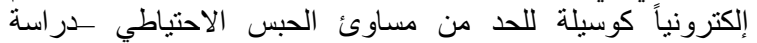

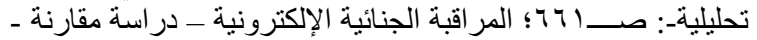

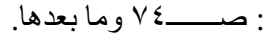

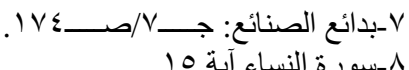

بما للإمام من ولاية في التعزير وفق ما يُحقق المصلحة، والتشهير من هذا الباب فيه أثر لردعاه أولاً، وتحذير الناس من التعامل معه ثانياً. V- الجمع بين عقوتين: وذلك كالجمع بين الغرامة والتشهير مثلاً، فلولي الأمر أن يحكم بما يرى فين فيه

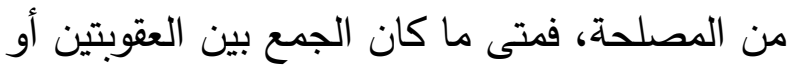
أكثر رادعاً فعله، كما فعل عمر مع معن بن زائدة فقد ضربه ونفاه ['] [r] 1-الإتلاف: ويقتضي أن يتلف ولي الأمر مكان الجناية أو إزالتها ونحوه، فهو أخذ الثيء من مالكه ولئه

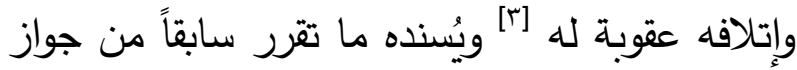
التعزير بالمال. ولا يدخل بيت المال؛ لعدم جواز

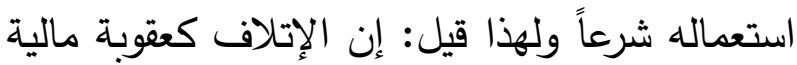
هو للأشياء التي لا يجيز الإسلام الانتفاع بها

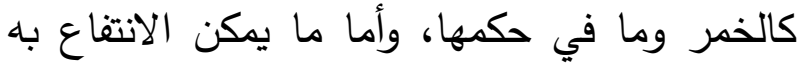
فيصادر للاستفادة منه [ـأ.

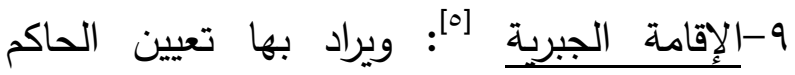
للمحكوم عليه موضعاً ليقيم فيه، سواءً كان منزله أو

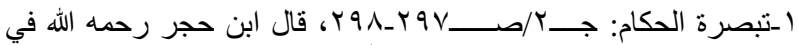

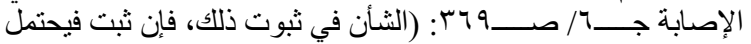

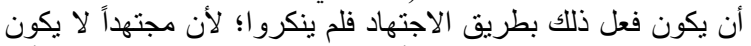

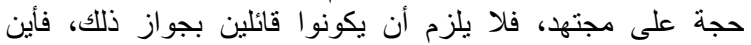

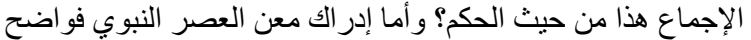

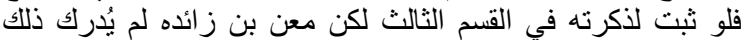

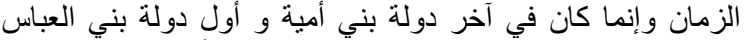

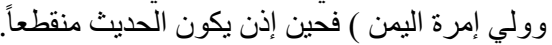

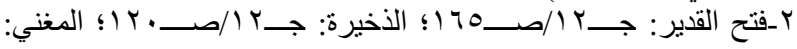
ج

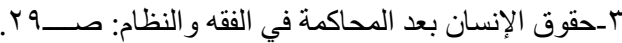

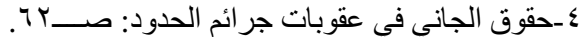

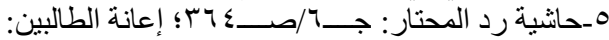

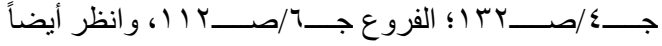

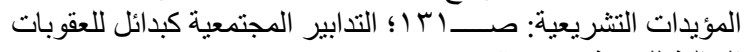

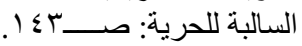


قال ابن تيميه: الحبس الشرعي ليس هو السجن في مكان ضيق وإنما هو تعويق الشخص ومنعه من التصرف بنفسه سواء في بيت أو مسجد []. با -نظام السجن المتقطع أو تقسيط العقوبة: حيث يقرر القاضي تنفيذ العقوبة بناء على طلب المحكوم عليه الأيام التي سينفذ فيه المحكوم عليه بالعقوبة السالبة للحرية قصيرة المدة عقوبته بصورة متقطعة مع مراعاة أن تتوافق هذه الإيام مع أيام العمل

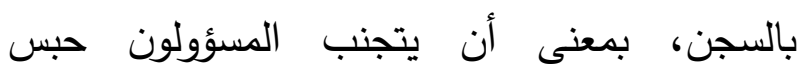
المحكوم عليه أيام العطلات أو الإجازات؛ وذلك حتى يستفيد المسجون من الاختبارات العامية والمعملية. وأوجه المعاملة الحديثة داخل السجون لإنيل التي تساهم في إصلاح المسجون واكتشاف شخصيته وعلاج ما فيها من انحراف وإعادته إلى صفوف المجتمع. ع ا-الوعظ: وهو النصح والتذكير بالعواقب، حيث يُوعظ الجاني ويُذكر إن كان ناسياً فينْبه إلى ما أقدم عليه من قول أو فعل [؛]. ويكو عادة في الجرائم البسيطة ويُعد من أنفع العقوبات النفسية في صلاح

الأفراد [0]

1 -الجلد: وقد أقرت هذه العقوبة مجموعة دول منها إنجلترا وأمريكا وهو اعتراف بأن عقوبة الجلد التي إحدى العقوبات الإسلامية كافية في ردع المجرمين عوضاً عن عقوبة السجن التي أثبتت فشلها باعتراف

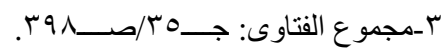

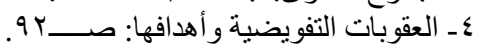

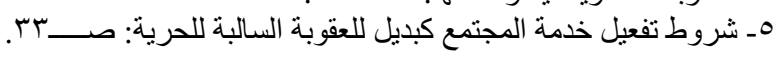

يُحبس بدار لا يباشر إلا أهلها لا يخرج منها أو لا يباشر إلا أشخاصاً أو شخصين فهذا هو الممكن فيكون هو المأمور به [1" • ا-الإلزام بإزالة الأضرار وتعوبض الهون المجني عليه: بحيث يجوز للمحكمة بناءً على طلب من المجني عليه أن تحكم على الفاعل بإزالة الأضرار التي أحدثتها جريمته وتعويض المجني عليه، وفي حالة رفض المحكوم عليه ذلك تُطبق عليه العقوبة الأصلية [ب]

1ا-التعهد والكفالة بحسن السلوك: وهو أن تحكم المحكمة على المدان بأن يقدم تعهداً بحسن السلوك وهو لمدة معينة إذا كانت الجريمة جنحة على أن يُودع المحكوم عليه في صندوق المحكمة مبلغاً من المال تراعي المحكمة في تقديره حالته المالية ولا يرد لله في حال إخلاله بتعهده. r ا-السجن شبه المفتوح: وهذا يمثل نموذجاً آخر للبدائل لنظام السجن التقليدي. ووفقاً له يُترك المذنب نهاراً لعمله ثم يعود ليلاً إلى السجن. ويُعتبر السجن شبه المفتوح أحد عناصر السياسة العقابية الحديثة؛ وذلك نظراً لفشل السجن التقليدي المنغلق على احلى الإنسان؛ لكونه وسطاً محكم الغلق من جهة، ونظراً لاستحالة ترك السجن مفتوحاً تماماً من جهة أخرى.

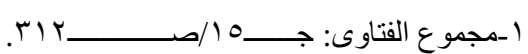

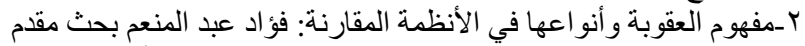

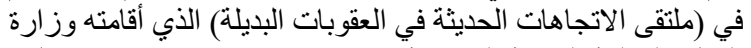

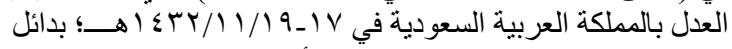

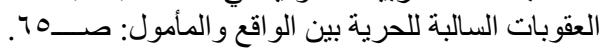


وبالإضافة إلى هذه العقوبات التعزيرية الأكثر تطبيقاً لاى القضاة، هناك الكثير من العقوبات التعزيرية

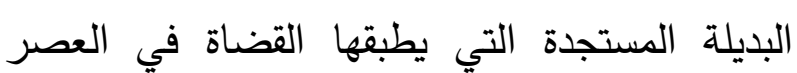
الحاضر للحد من بعض المخالفات والمعاصي والجرائم المستجدة كلما دعت المصلحة إلى ذلك. ومن هذه التعزيرات المستجدة التي لا يمنع الإسلام من تطبيقها ما دامت تعمل على الحد من الجرائم [־]:

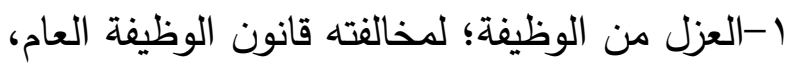

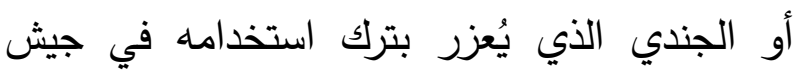
المسلمين كالجندي المقاتل إذا فر من الزحف؛ فإنه من كبائر الذنوب، وكذلك إنزال رتبته وقطع أجرته.

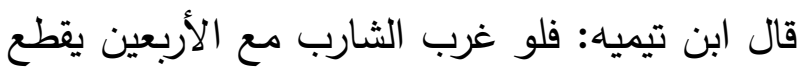

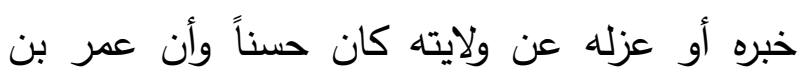
الخطاب رضي الله عنه بلغه عن بعض نوابه يتمثل بأبيات من الخمر فعزله [ـ]

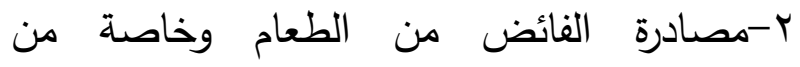

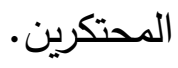
ז-هدم البيوت التي تدار للفسق والفجور • ع-عقوبة التهديد وهي عقوبة تعزيرية شرعية تحذر لهرب

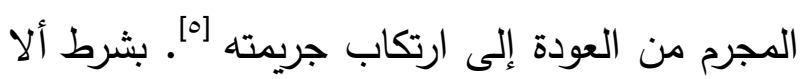
يكون تهديداً كاذباً وأن يرى الحاكم أنه منتج وأنه النه يكفي لإصلاح الجاني وتأديبه، وذلك مثل أن ينذره القاضي بأنه إذا عاد سيعاقبه بالجلد أو الحبس أو وتئه

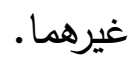

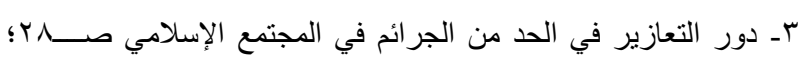

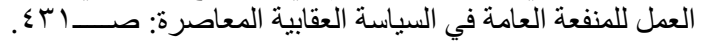

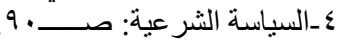

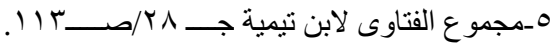

باحثين كُثر مثل الدنماركي (فلامنجغ بالفينغ) والنرويجي (توماس ماتييسن) وغيرهم [1] 7 ا-الإفراج الشرطي [־]: وهو إطلاق سراح السجين وغين من المؤسسة قبل استكمال مدة حكمه؛ وذلك بوضعاه تحت مراقبة أو إشراف معين. وشروط الإخراج إما أن تكون مقررة بقانون أو موضوعة من قبل سلطة إنساف الإفراج الشرطي، ولذلك فإن المراقبة القضائية والإفراج الثرطي يتشابهان من حيث إنهما يتوقفان

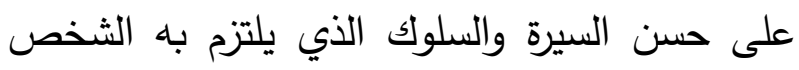

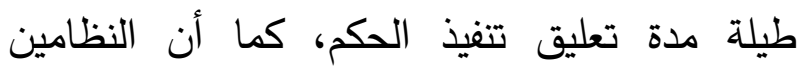
يستلزمان وجود باحث اجتماعي، أو مراقب معين

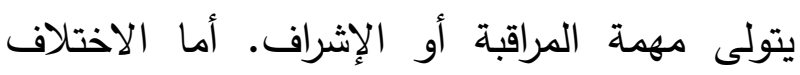
الجوهري بين النظامين فهو أن المراقبة القضائية تعليق تتفيذ الحكم برمته، وقبل إرسال المجرم إلى انى السجن بينما الإفراج الشرطي تعليق جزء من الحكم فحسب، كما أن المراقبة القضائية حق للمحكمة الجنائية وحدها بينما يُوكل أمر الإفراج الشرطي إلى إنى

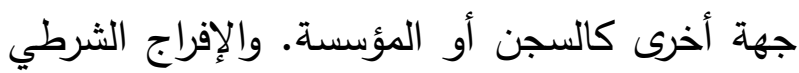
طريق لإطلاق سراح بعض المجرمين بالاختبار وقبل

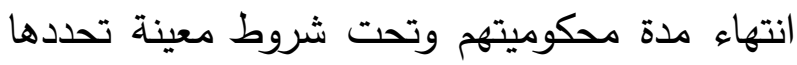
سلطة مختصة. فهي تقنية إصلاحية لإطلاق سراح المجرم من سجنه تحت مراقبة منظمة تهدف إلى فئل حماية المجتمع من المجرم أو تقويمه.

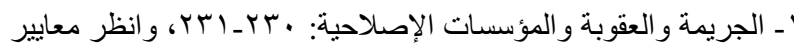

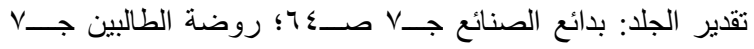

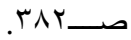

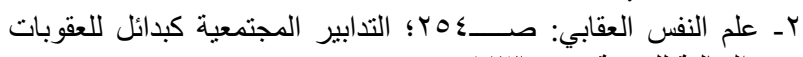

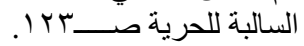


أما عن تطبيق البدائل في المملكة. فهذه البدائل لم يُقر تطبيقها بنص قانوني حتى الآن، ولم تُحدد

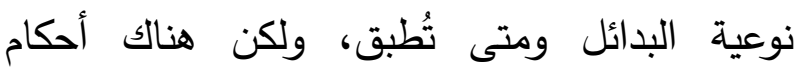
أصدرها بعض القضاة تتاولوا فيها بعض ما ذكرنا

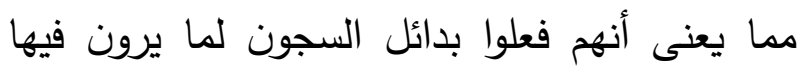
من نفع للسجين والمجتمع.

المطلب الرابع: الآثار الإيجابية للعقوبات البديلة لا شك بأن هناك جرائم لا تقتضي إيقاع العقوبة الإبهابة

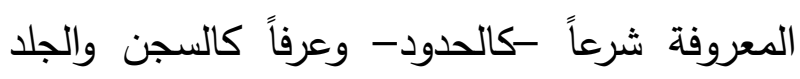
والغرامة المالية. وأقصد هنا بعض القضايا اليسيرة والتي يكون السجن عقوبتها عادةً كالديون المستحقة والمماطلة فيها وبعض الجنح الطفيفة وما إلى ذلك، فايجاد البديلة هنا لا يكون فيه إخفاق بالحقوق العامة

والخاصة ولا معارض للأنظمة المعمول بها. وخرجت - باليسيرة -القضايا الكبيرة التي من شأنها أن تهدد أمن الأمة وكيانها (كالإرهاب وترويج المخدرات) فهذه لا تدخل تحت نطاق الأحكام البديلة؛ لأن عقوبتها منصوص عليها بحد الحرابة لهابة وقطع الطريق، كما يشمل الاستثناء كذلك أرباب السوابق -كما أسلفنا-. وهناك بعض الفئ الفوائد للعقوبات البديلة التي تُطبق في هذا المجال وهي التي دعت التبات المختصين للمطالبة بها وتفعيلها لانعكاسها ايجاباً على الفرد والمجتمع ونجملها بالآتي [']:
0-سحب رخصة الترخيص لصاحب المحل لمخالفته قوانين ومواصفات المهنة أو صاحب السيارة المخالفة أو لمخالفته إشارات المرور • 7-مساعدة موظفي البلدية في قطع زوائد الأشجار

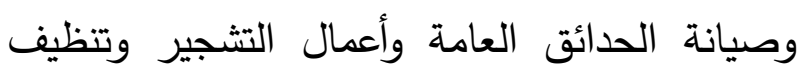
الشواطئ. V-رفع الأذان لمدة شهر كامل.

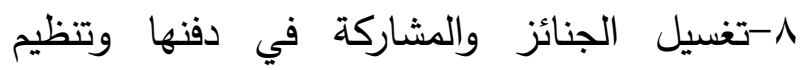
وترتيب محتويات مغاسل الأموات. 9-القيام بتقديم المساعدة في قسم الإسعاف في المشافي العامة، والمناوبة في مراكز الدفاع المدني.

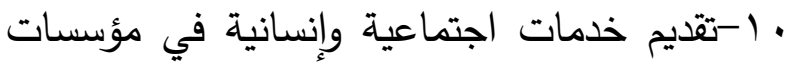

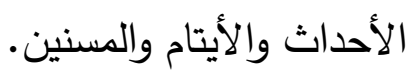
1ا-المشاركة في مجال خدمة حجاج بيت الله الحرام من خلال إلحاقه بالكثافة. وغيرها من العقوبات التعزيرية البديلة التي تضعها الدولة، شريطة أن يترك المجال للقاضي في التطبيق

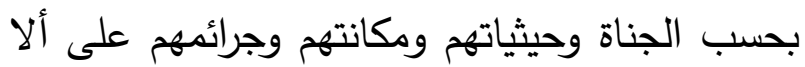
يغيب عن أذهاننا بأن المقصد الرئيس من إيقاع

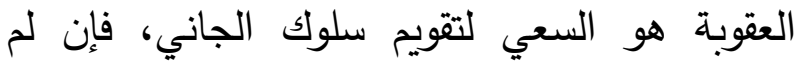
يحصل منها هذا المقصد لم يكن لإيقاعها الهذف المراد من العقوبات. ولعل خير مثال يذكر على ذلك لهائ مركز الأمير محمد بن نايف للمناصحة والرعاية وهو مشروع رائد نجح في معالجة قضايا الإرهاب ورد الكثير إلى جادة الصواب وكان ذلك أفضل من لهن 
ألزم فيه أو في غيره، ومن المعلوم أيضاً أن كافة

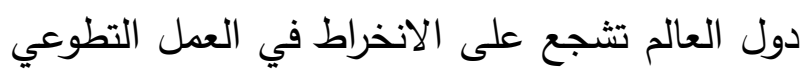
وتحث عليه. V-المحافظة على الروابط الاجتماعية والأسرية، وتوفير سبل المعيشة لأسر المسجونين، والتخلص الإستاعية والاسرية

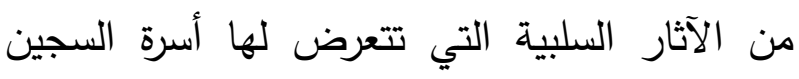
نتيجة سجن عائلها وتتنوع من طلاق وانحراف لهن للأبناء وفقر مما يؤدي لحدوث تفكك في تلك الأسر وتغير في وظائفها بالإضافة إلى نظرة المجتمع لمن لند يسجن. ^-الزجر والردع لسائر أفراد المجتمع عن ارتكاب

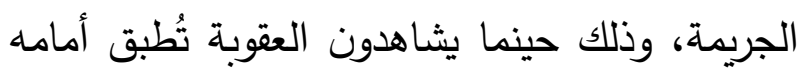
في المرافق العامة بجدية وانضباط وهذا من أهم مقاصد عقوبة التعزير • • 1- دمج الجاني بالمجتمع حال خدمته له بالأعمال

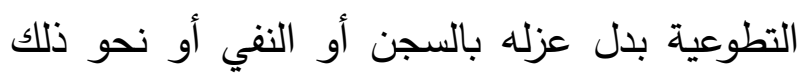

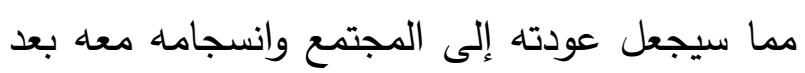

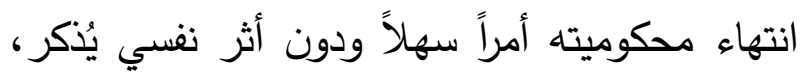
وهنا تبرز أهمية الاتصال والدمج بالمجتمع؛ إذ يمكنه تخفيف صدمة الإقراج التي تصيب المحكوم عليه بعد فترة العقوبة والوصمة المجتمعية التي تلاحق من الإندي يُسجن وتؤدي إلى نفور أفراد المجتمع وزملائه

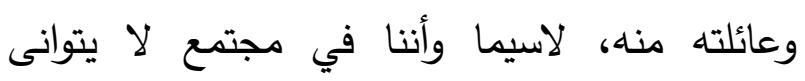

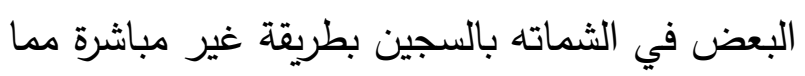

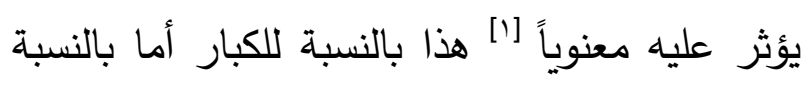

1-معالجة مشكلة تكس واكتظاظ السجون بالسجناء، وما يصحب ذلك من آثار ومشكلات نفسية وصحية. r-ضمان عدم مخالطة المقترفين لبعض الجرائم البسيطة أو المذنبين مع عتاة المجرمين وأصحاب السوابق الجنائية الكبيرة والخطيرة ومرتكبي جرائم الحدود؛ حتى لا تصبح السجون مدارس لتعليم الإجرام فيخرج الشخص محترف بسبب لأهب تأثير الآخرين الموجودين معه في السجن مما يجعل منه وسيلة غير مناسبة للإصلاح والتهذيب. ب-حماية الشخص نفسياً وجسدياً واجتماعياً. ع-التقليل من نفقات السجون وتحويل ميزانيتها إلى مشاريع إنتاجية تدر الخير على الفرد والمجتمع؛ فاللجوء إلى البديلة يخفض النفقات الباهظة المترتبة

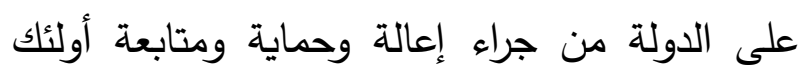
المسجونين، والتركيز على زيادة فرص تطبيق برامج إعله

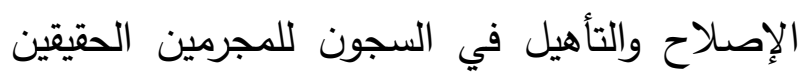
والخطرين. ๑-جلب الفائدة على المجتمع من خلال خدمات النفع الاجتماعي -التي يقوم بها الأثخاص المطبق هن

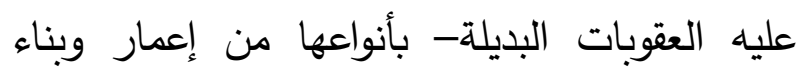
وغيرها.

؟-تدريب الجاني على العمل التطوعي بحصوصد

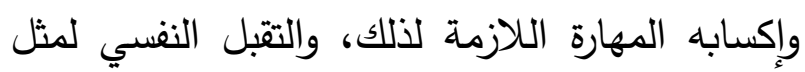
هذه الأعمال مما يدفعه إلى الاستمرار في خدمة لهابه

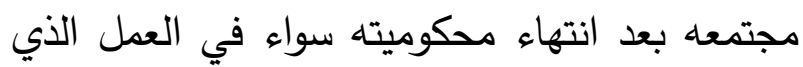


تحديده من أحكام الحدود. والعقوبات البديلة لها حكم التعزير؛ إذ هي أفراد داخله تحت اسمه، وبالمقابل فإن كل فرد من أفراد التعزير يصلح أن يكون بديلاً عن السجن إذا توافرت فيه شروط البدلية وانتفت عنه الموانع الشرعية. والأصل في التعزير ثبوت شرعيته إجمالاً من الكتاب والسنة والإجماع، ويزيد طائفة من الأصوليين في مشروعية السجن أنه من باب المصلحة المرسلة ويسندون اتخاذ الصحابة مكاناً معيناً للسجن إلى تلك المصلحة؛ إذ لم يكن عندهم في ذلك نص خاص قولي أو فعلي [']. إذاً منطلق الأحكام البديلة يأتي من أحكام التعزير في الفقه الإسلامي، والعقوبات البديلة هي عقوبات أصلية قبل أن تكون بديلة، وإنما تعتبر بديلة لما هو أشد منها إذا امتتع تطبيق العقوبة الأشد -كما بيّنافالتعزير عقوبة أصلية في جرائم التعازير، ولكن يُحكم به بدلاً من القصاص أو الحد إذا امتتعا لسبب

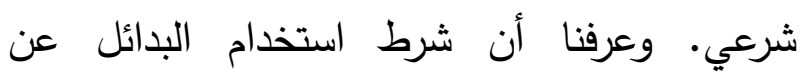
التعازير أن يحقق البديل مصلحة للمجتمع وللمتهم، وما يزيد في مرونة العقوبات التعزيرية وقابليتها لتطبيق بدائل عنها أنه لا حصر للعقوبات التعزيرية وبالتالي فلا حصر للبدائل التي يمكن تطبيقها إزائها، مما يأتي تحت مسمى المصلحة العامة التي جاءت

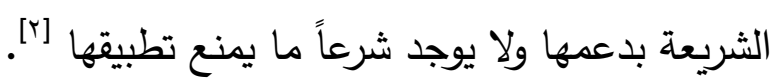

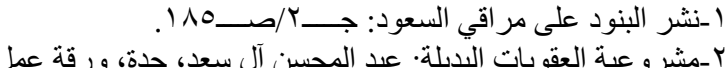

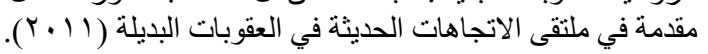

للأحداث فاشترط مشروع النظام عدم إبعاد الصغار عن الجو العائلي واستمرارهم في الدراسة ضمن ضوابط معينة مقدرة سلوكياً ومجتمعياً ونفسياً مع التشديد على استعانة القضاء بالخبرة الاجتماعية والنفسية في الوقائع المتعددة التي لا يحكمها ضابط معين مع حفظ حق المجتمع بالنسبة لجنوح الطفل والتحفظ من تأثير سلوكياته السلبية على غيره. ا1-تغيير نظرة المنحرفين لأنفسهم ولانتمائهم الوطني وتعزيز الشعور بهذا الانتماء؛ فالبديلة أنفع للوطن وأهون على المتهم. r ا-العقوبات البديلة تتمخض عن أساليب متعددة للعقاب الأمر الذي يمنح المحكوم عليه فرص للتوبة وإصلاح ومحاسبة النفس، والعدول عن طريق

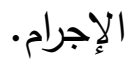

ولهذه الفوائد الجمة تحركت المؤسسات القضائية والعقابية والجهات التنفيذية لتفعيل أنواع من العقاب تخرج عن دائرة العقوبة السجن فأعدت الأنظمة واللوائح المبدئية والإسترشادية والدراسات لتقرير بدائل عقابية متنوعة تطرح أفقاً واسعاً لمفهوم العقاب. المبحث الثالث: العلاقة بين الأحكام البديلة والتعزير ذكرنا بأن أحكام التعزير تصدر في نوعين من الجرائم. أحدهما: ما لم تُؤكد البراهين القاطعة أنه مدا يستوجب تطبيق أحكام الحدود كالخلوة التي لا يقوم فيها دليل قاطع على ارتكاب الفاحشة. والثاني: الذي تصدر فيه أحكام التعزير هو تلك الجرائم المستحدثة التي لم تكن معروفة من قبل، ولا تتدرج تحت ما تم 
النفقات المصروفة عليهم مما له مردوده الاقتصادي بتوفير المبالغ الكبيرة، لاسيما وأن هذه البديلة هي بدائل عقابية متتوعة وموسعة لمفهوم العقاب تهدف إلى دفع الجريمة وحصر آثارها السلبية. - إن إقرار العقوبات البديلة يمثل إضافة علمية لها طابع تفصيلي لفتح باب الاجتهاد أمام الفقهاء والقضاة للبحث والدراسة للوصول إلى قواعد محكمة ومؤصلة؛ لذلك فهي تسهم في بناء فقهي سديد واستجلاء النصوص والحالات والوقائع المساندة لهذه

العقوبات والتقعيد لها لاسيما المستجد منها. - تتميز العقوبات البديلة بالخصائص التالية: ا-ردع للجاني وعضة للغير وبذلك هي تشتمل على أهم مقومات العقوبة الحديثة. r-ترك للقاضي مجالاً واسعاً في تقدير العقوبة ونوعها دون إهمال النظر للجاني. ب-أنها ليست بلازمة بل يمكن اختيار المناسب منها أو العدول إلى غيرها مما ليس فيه خروج على أحكام الشريعة وروحها ومقاصدها العامة. ع-العقوبات البديلة وإن كانت متروكة للاجتهاد إلا أنها لا تخرج عن القواعد العامة للشريعة الإسـلاية والمقاصد الكلية للإسـلام بما يوازن بين حق المجتمع في الحماية من الإجرام وحق الفرد في تحصين حرياته ورعاية حرماته. ○-من خصائص العقوبة في الإسلام ترضية المجني عليه أو أهله لدرجة أنه لا توجد شريعة عقابية تسعى إلى استرضاء المجني عليه بشكل مباشر أو أهله

\section{الخاتمة}

قد تبين بجلاء من خلال مناقشة وتحليل مفهوم البدائل في ثنايا هذا البحث أنها ليست أحكاماً تمييعية ولا ترفاً عقابياً، بل ضرورة تمليها المرحلة المعاصرة وما وصل إليه العلم من حقائق حول الفوائد التي تحققها على صعيد الأمن واستقرار المجتمع وتماسك الأسرة والتنمية وحقوق الإنسان وعلى سلوك الجاني وسلامته من التنكيل والإيلام البدني والنفسي. كما أن تطبيق العقوبات البديلة في الجرائم التعزيرية سيؤدي إلى إبراز محاسن الشريعة، والذب عن الدين وحفظ حقوق الإنسان وكرامته وتحقيق العدالة من الناحية السياسية وتهذيب وإصلاح الجاني وحماية أسرته من الآثار السلبية للعقوبة التقليدية، وكذلك تأهيل الجاني وزيادة الناتج الوطني وتخفيف الأعباء على الدولة. والعقوبات البديلة تعتبر من الأحكام القضائية الجديدة لدى بعض القضاة التي يتوجب تفعيلها والأخذ بها؛ نظراً للحاجة الماسة للاستفادة من طاقات الثباب في خدمة المجتمع بدلاً من تعطيلها وكبتها في السجن، وحماية لذوي الجنح الصغيرة من الاختلاط بأرباب السوابق والإجرام. ثم أن إقرار مبدأ العقوبات البديلة سيكون عوناً لدمج فئة معينة أخطأت في المجتمع وتقديم كافة أشكال الرعاية المختلفة للمخطئ اجتماعياً ونفسياً وطبياً، بدلاً عن تأثرهم بالإجرام وحرمانهم من الوظيفة أو انقطاعهم عن الدراسة. والمساهمة في التخفيف من أعباء السجون وتقليل 
- العقوبة البديلة في الواقع عقوبة شرعية وتستتد إلى تكييف شرعي، وإن لم يكن نص شرعياً بعينه؛ لأننا إذا قلنا نص شرعي في عقوبة فهي عقوبة مقدّرة، والعقوبات المقدرة لا مجال للحديث فيها. أما أهم التوصيات فهي كالآتي: ا-حث القضاة على تفعيل العقوبات البديلة، لآثارها

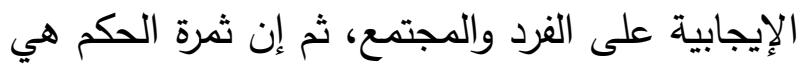
التتفيذ الفعال فإنه لا خير في حكم لا نفاذ له.

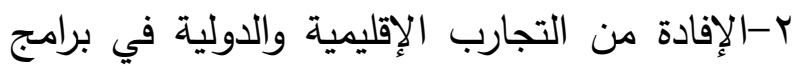
تطبيق العقوبات البديلة. r-استغلال وسائل الإعلام المرئية والمسموعة والمقروءة لتهيئة الرأي العام لتقبل فكرة تطبيق خدمة

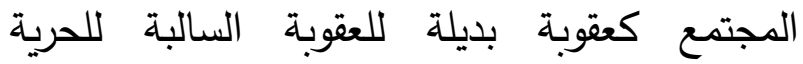
(السجن)، وذلك من خلال المقارنة بين إيجابياتها

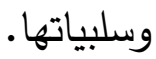
ع-الاهتمام بنشر الوعي الاجتماعي بأهمية العقوبات البديلة في المجتمع عن طريق الدورات والبرامج

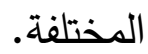

0-الحرص على توجيه العلماء والباحثين على استتباط العقوبات المناسبة للجرائم التعزيرية تكون

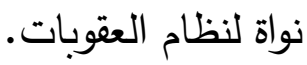
ج-التعاون مع الجهات الأمنية وبأساليب حديثة في المتابعة والتتفيذ. V-وضع دليل معتمد يتضمن الجرائم التي يوضع

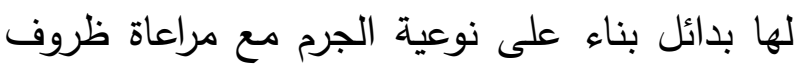
الجاني النفسية والعائلية والمادية سوهي أمور معتبرة
كقدر عناية الثريعة بها، وهذه الخاصية موجودة في البديلة بل هي أساسها. צ-العقوبات البديلة لا تعني إقصاء عقوبة السجن ولكن بجعلها ملاذاً أخيراً يلجأ إليه القاضي بحسب ألباء خطورة الجريمة وشدتها، على ألا يكو السجن حكماً

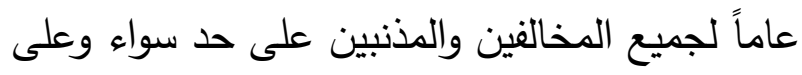
اختلاف جرائمهم؛ مما يسهم في تدهور حال المذنب

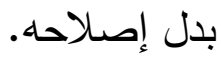
V ليس في هذه البدائل مخالفة للشرع أو تتازل عن العقوبة الثرعية، بل فيه مسايرة لظروف العصر . 1-جوهر هذه العقوبات يقوم على توفير معاملة عقابية خاصة تنطوي على التهذيب من خلال العمل وتقود بذلك إلى التأهيل دون أن تؤدي إلى سلب عندي

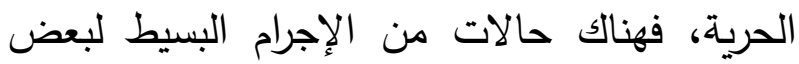
الفئات يكون من الأفضل فيها أن يُترك المحكوم

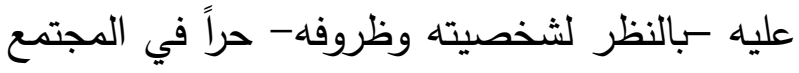
مع خضوعه للتأهيل والتوجيه وذلك من خلال إلزامه

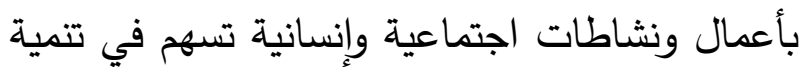
شعوره بالمسؤولية وتتيد حريته على نحو يجعله يفكر جدياً بما أقدم عليه، فهي تعمل على إصلاح وتهذيب وليب المحكوم عليه من خلال إبعاده عن الوسط الإجرامي داخل السجن؛ وكذلك ما تحمله من دعم وغرس لقيم العمل التطوعي بين أفراد المجتمع.

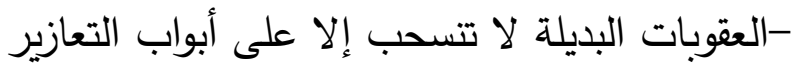
وهي ما لا نص شرعي في تقدير عقوبتها. 
ع- الأشباه والنظائر: جلال الدين عبد الرحمن السيوطي، دار الكتب العلمية، بيروت لبنان،

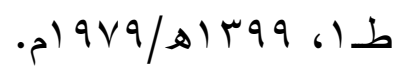

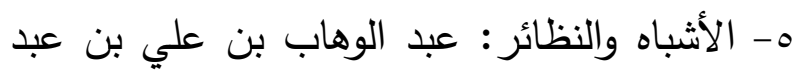

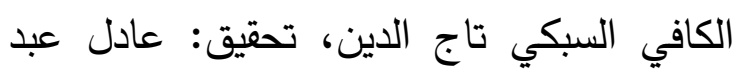
الموجود وعلي عوض، دار الكتب العلمية،

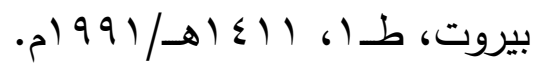

7- الاعتصام: إبراهيم بن موسى الثاطبي، مطابع

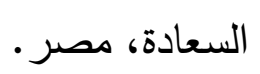

- الإلزام بالأعمال التطوعية في العقوبات التعزيرية: عبد العزيز محمد الحجيلان، ورقة عمل مقدمة لحلقة النقاش التي يعقدها مركز

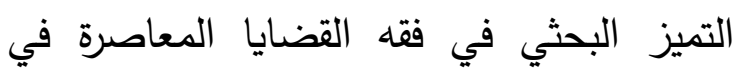
جامعة الإمام محمد بن سعود الإسلامية

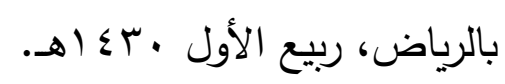

^- الأموال: لأبي عبيد القاسم بن سلام بن عبد الأبد الله الهروي البغدادي، تحقيق: د. محمد عمارة، دار

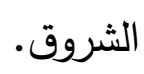

9- الإنصاف في معرفة الراجح من الخلاف: علاء الدين أبي الحسن علي بن سليمان المرداوي، مطبعة

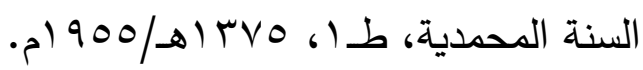

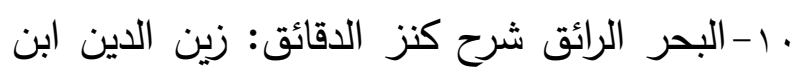
نجيم الحنفي، دار المعرفة، بيروت، لبنان.

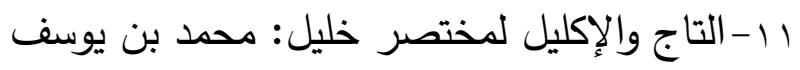
بن أبي القاسم العبدري أبو عبد الله، دار الكتب الإكلي

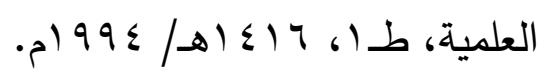

في الفقه الإسلامي-لاسيما وأن درء المفاسد مقدم على جلب المصالح. وهذا يقتضي تأهيل القضاة للاجتهاد في تحديد العقوبات المشروعة والملائمة لتحقيق التهذيب والإصلاح والتأهيل للجاني وتضمن فئن في الوقت نفساه توفر الردع والنفع العام. 1-عقد المؤتمرات العالمية للتوصل إلى نظام عقابي لتودي بديل مجمع عليه وحتى لا يحصل تفاوت كبير بين

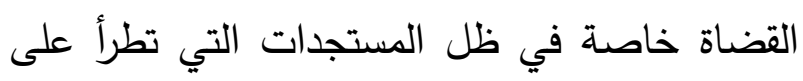
الساحة سواء كانت اقتصادية أو اجتماعية أو غيرها. 9-العمل على توسيع دائرة عمل العقوبات البديلة لتشمل جميع الأعمال التي فيها منفعة للمحكوم عليه وغيره من زراعية وبلدية واجتماعية وأمنية.

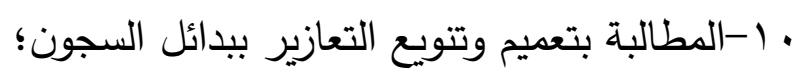

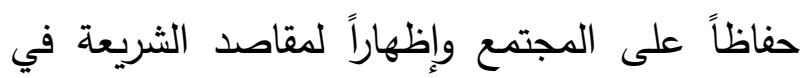
العقوبة.

\section{قائمة المصادر والمراجع}

1- أصول علم الإجرام وعلم العقاب -دراسة تحليلية

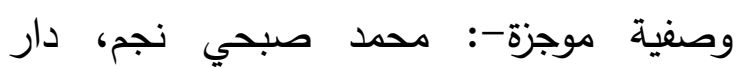

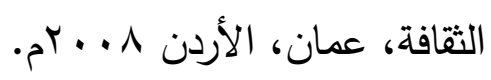

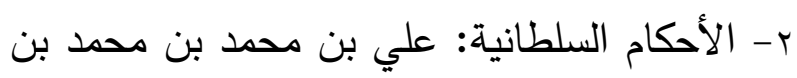

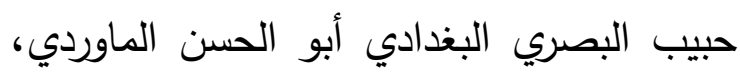
دار الحديث، القاهرة. r- الأحكام السلطانية: محمد بن الحسين بن محمد العدان بن خلف ابن الفرّاء القاضي أبو يعلى، تعليق:

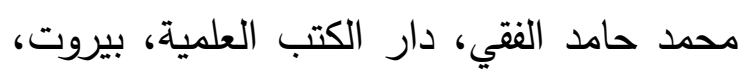

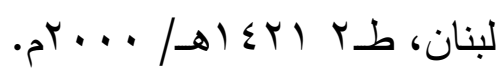


• ץ-الذخيرة: أبو العباس شهاب الدين أحمد بن إدري بن عبد الرحمن المالكي الثهير بالقرافي،

$$
\text { بيروت، ؛ } 99 \text { (م. }
$$

اץ-السنن الكبرى: أبي بكر أحمد بن الحسين بن علي البيهقي، دار الفكر ، بيروت. r r-السياسة الشرعية في إصلاح الراعي والرعية: أحمد بن عبد الحليم ابن تيمية، بيروت، دار المعرفة. rץ-الطرق الحكمية في السياسة الثرعية: ابن القيم الجوزيـة، تحقيق: محمد جميل غازي، مطبعة المدني، العباسية، القاهرة. ع -الظروف المخففة والمشددة في عقوبة التعزير في الفقه الإسلامي: ناصر علي ناصر الخليفي، القاهرة، مطبعة المدني. ه - العفو المشروط بحفظ القرآن الكريم أو أجزاء منه داخل السجن: عيسى عبد العزيز الشامخ، مكتبة العبيكان، الرياض، 9 1ـ الهـ جr-العقوبات التفويضية وأهدافها في ضوء الكتاب والسنة: مطيع الله دخيل سليمان الصلهيد، جدة، دار تهامة للنشر . V V-العمل للمنفعة العامة في السياسة العقابية المعاصرة -ـراسة مقارنة-: د. صفاء أوتاني، مجلة جامعة دمشق للعلوم الاقتصادية مجلد (r) 9 ـ . . rم. ^ץ-الفتح الرباني في ترتيب مسند الإمام أحمد الشيباني: أحمد البنا الساعاتي، القاهرة، دار

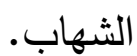

r -التأهيل الاجتماعي في المؤسسات العقابية: مصطفى العوجي، بيروت، منشورات بحسون، . 994 rا-التدابير المجتمعية كبدائل للعقوبات السالبة للحرية: عبد الله عبد العزيز اليوسف، الرياض، جامعة نايف للعلوم الأمنية، ع \& أهـ. ع ا-التشريع الجنائي الإسلامي: عبد القادر عودة،

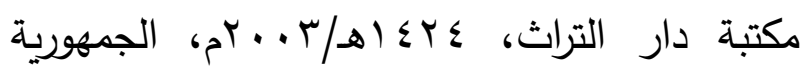
العربية المتحدة، القاهرة. ه - التعزيرات البدنية وموجباتها في الفقه الإسلامي: عبد الله صالح الحديثي، مكتبة الحرمين، الرياض،

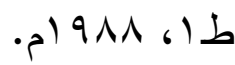
1 ا-الجامع لأحكام القرآن: أبو عبد الله محمد بن أحمد بن أبي بكر بن فرح الأنصاري الخزرجي شمس الدين القرطبي، دار الكتب العلمية، بيروت، - $) 9 \wedge 1$ V - الجرائم الجنائية وعقوباتها المقدرة في التشريع الجنائي الإسلامي: حسن عزة، دار الرياض للنشر

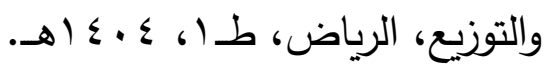
1 ا - الجريمة والعقوبة والمؤسسات الإصلاحية: حسن

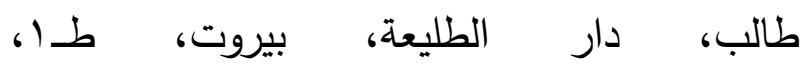
r 9 1 - الخلاصة في أحكام السجن في الفقه الإسلامي: علي بن نايف الشحود، طـا معدلة ومزيدة، r 
وץ-المهذب في فقه الإمام الثافعي: أبو إسحاق إبراهيم بن علي بن يوسف الثيرازي، تحيق: محمد

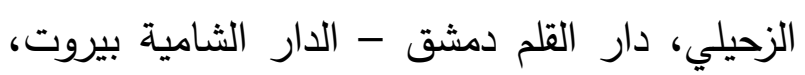

$$
\text { طـ إه اله }
$$

• ـ - النظرية العامة للقانون الجنائي: رمسيس بهنام، منشأة المعارف، الإسكندرية، طـ ب، 99 (م. اء-الوضع تحت المراقبة الإكترونية؛ السوار الإككتروني في السياسة العقابية الغرنسية؛ مجلة جامعة دمشق للعلوم الاقتصادية والقانونية المجلد

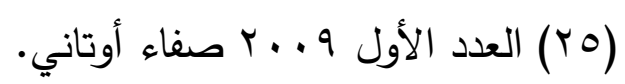
rـ-بدائع الصنائع في ترتيب الشرائع: أبو بكر بن مسعود الكاساني الحنفي علاء الدين، تحقيق: علي محمد معوّض - عادل أحمد عبد الموجود، دار

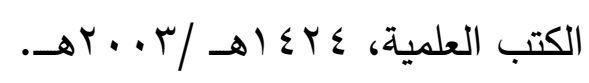
rی - بدائل السجن دراسة مقارنة: حجاب بن عائض الذيابي كسالة ماجستير من جامعة الإمام محمد بن سعود الإسلامية - (المعهد العالي للقضاء- قدم السياسة الثرعية) إشراف: د. منصور نصر قموح، . . . . . عـ-بدائل السجن - دراسة فقهية-: د. د. الطيب السنوسي أحمد. 0ـ-بدائل السجون (الأحكام البديلة): د. ياسر البلوي، المصدر الجوريس بيديا.

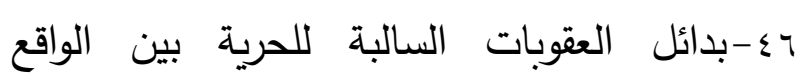
والمأمول: عبد الله علي الخثعمي، جامعة نايف qr-الفروق: أحمد بن إدريس بن عبد الرحمن القرافي، عالم الكتب، بيروت.

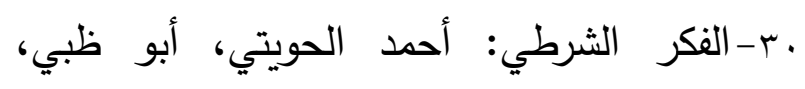
الإمارات العربية، بو9 أم. اب-القواعد الفقهية الكبرى وما تفرع عنها: د. صالح

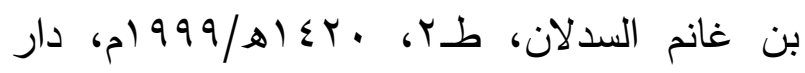
بلنسية السعودية. rr-الكفارات في الشريع الإسلامية: عبد الله محمد القويزاني، طـا، 9 وب أهـ rr-المؤيدات التشريعية: عبد العزيز الخياط، دار

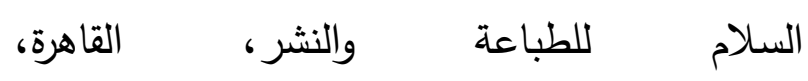

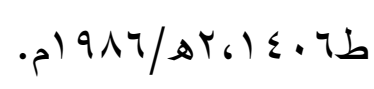

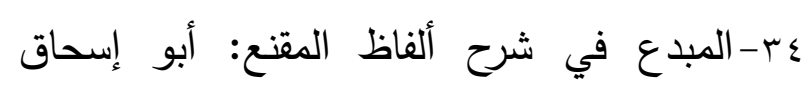
ابراهيم بن مفلح، بيروت، المكتب الإسلامي، . $1 \leqslant$. هץ-المبسوط: محمد بن أبي سهل السرخسي، دار المعرفة، بيروت، 7 ، ـ اهـ. بr-المراقبة الإلكترونية طريقة حديثة لتنفيذ العقوبة السالبة للحرية خارج السجن: عمر سالم، دار النهضة العربية، القاهرة، طـr. Vr-المراقبة الجنائية الإلكترونية -دراسة مقارنة-: أسامة حسنين عبيد، دار النهضة العربية، القاهرة،

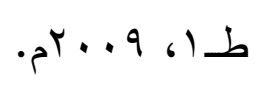

مبـ- المغني: موفق الدين أبو محمد عبد الله بن أحمد ابن قدامة المقدسي، مكتبة الرياض الحديثة. 


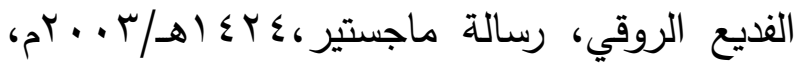
أكاديمية نايف للعلوم العربية. هـ-حقوق الجاني بعد صدور الحكم في الشريعة الإسلامية: معجب بن معدي العتيبي، مطبعة

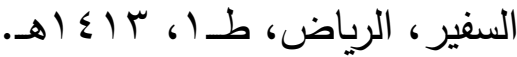

جه-حقوق الجاني في عقوبات جرائم الحدود: فواز ذعار العتيبي، جامعة الإمام محمد بن سعود

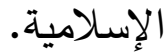

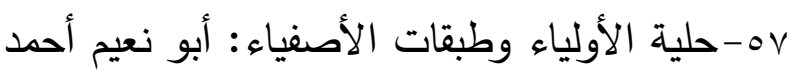
بن عبد الله الأصبهاني، دار الكتاب العربي، بيروت، طـ ^ه-دور التعازير في الحد من الجرائم في المجتمع

$$
\text { الإسلامي: د. فلاح سعد الدلو. }
$$

9ه-روضة الطالبين وعمدة المفتين: أبو زكريا محيي الدين يحيى بن شرف النووي، تحقيق: علي محمد معوض-عادل أحمد عبد الموجود، الرياض،

$$
\text { r }
$$

• ؟-زاد المعاد في هدي خير العباد: محمد بن أبي بكر أيوب الزرعي أبو عبد الله ابن قيم الجوزية، مؤسسة الرسالة، مكتبة المنار الإسلامية، بيروت-

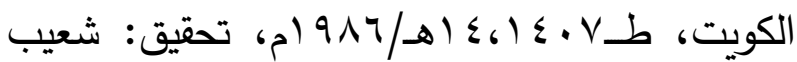
الأرنؤوط-عبد القادر الأرنؤوط. آ-سنن أبي داوود: أبو داوود سليمان بن الأشعث السجستاني الأزدي، تحقيق عزة عبيد دعّاس، مكتبة

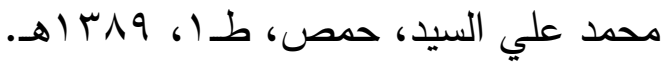

العربية للعلوم الأمنية قسم العلوم الاجتماعية،

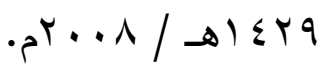
V乏 - تبصرة الحكام في أصول الأقضية ومناهج الأحكام: برهان الدين أبي الوفاء إبراهيم بن الإمام شمس الدين أبي عبد الله محمد بن فرحون اليعمري المالكي، بيروت، طـ ا، 7 (اء (هـ. ^乏-تجارب الدول الأخرى لبدائل عقوبة السجن: عبد الله بن عبد العزيز اليوسف، ضمن ندوة بدائل عقوبة السجن، الجمعية الوطنية لحقوق الإنسان،

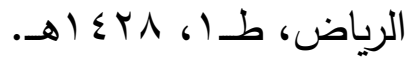
9؟-تحرير التبييه: لأبي زكريا يحيى بن شرف النووي، تحقيق: عبد الغني الدقر، دار القلم، دمشق، طـ إ، •- م-تداخل العقوبات في الثربعة الإسلامية: عادل

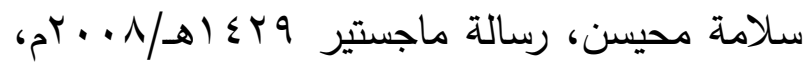
الجامعة الإسلامية، غزة. 10-حاشية الجمل على شرح المنهج: الشيخ سليمان

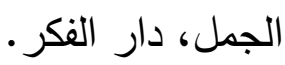
ro-حاشية الدسوقي على الشرح الكبير: محمد عرفه، مطبعة عيسى البابي الحلبي، القاهرة. به-حاشية رد المحتار على الدر المختار: محمد أمين بن عمر بن عبد العزيز بن عابدين الدمشقي،

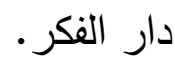
ع.-حقوق الإنسان بعد المحاكمة في الفقه والنظام وتطبيقاتها في المملكة العربية السعودية: محمد 
الح-قواعد الأحكام في مصالح الأنام: أبو محمد عز

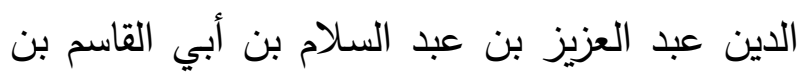
الحسن السلمي الدمشقي، دار الكتب العلمية.

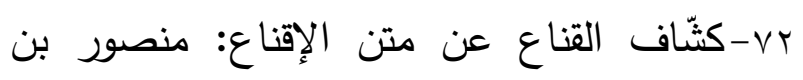
يونس البهوتي، دار الكتب العلمية، بيروت.

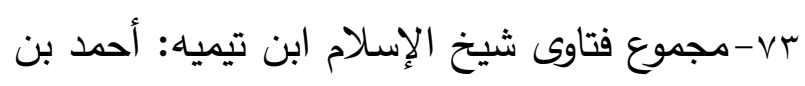

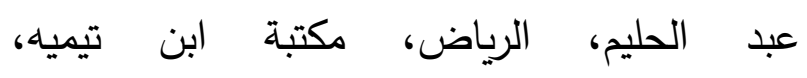

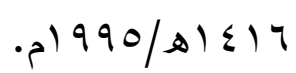
ع ع-1اقبة المتهم إلكترونياً كوسيلة للحد من مساوئ

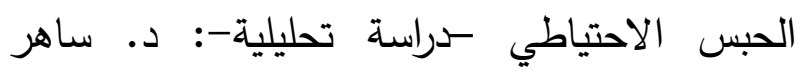
ابراهيم الوليد، مجلة الجامعة الإسلامية للدراسات الإسلامية، المجلد الحادي والعشرون، العدد الأول، الجالئ th

ه-مرشد إجراءات الحقوق الخاصة: وزارة الداخلية،

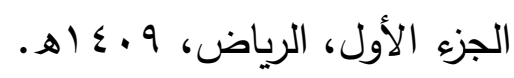

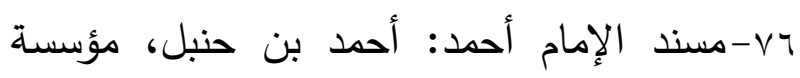

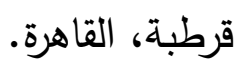

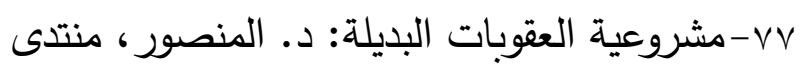

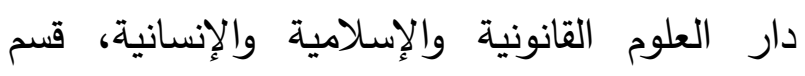
القانون الجنائي الإسلامي.

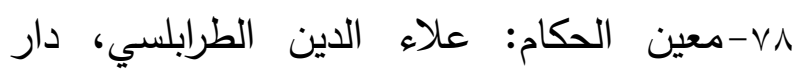

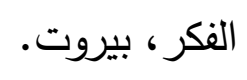

99-مغني المحتاج إلى معرفة ألفاظ الدنهاج: شمس الدين محمد بن أحمد الخطيب الشربيني، دار الفكر الفرانيا rآ-سنن الترمذي: أبو عيسى محمد بن عيسى بن سورة، بيروت، دار إحياء التزراث العربي. بآ-سنن النسائي: أبو عبد الرحمن أحمد بن شعيب التربي

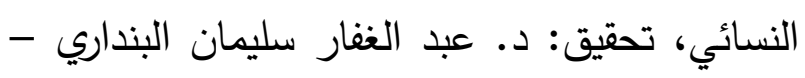
سيد كسروي حسن، بيروت، دار الكتب العلمية، . $1991 / 81 \leqslant 11$

ع آ-شرح صحيح مسلم (المنهاج): للنووي، تحقيق: عادل عبد الموجود - علي معوض، مكتبة نزار

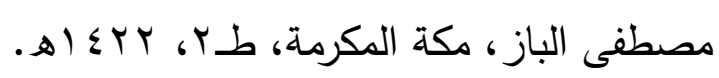
07-شروط تفعيل خدمة المجتمع كبديل للعقوبة الهبارية السالبة للحرية من وجهة نظر الضباط والنزلاء في إصناحية الحائر: ثامر ضيدان العتيبي، الرياض، 苗 بو-علم النفس العقابي -أصوله وتطبيقاته-: كمال

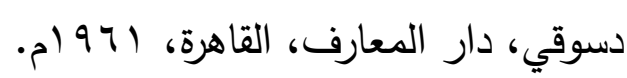

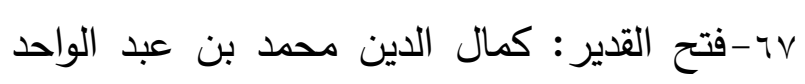
المعروف بابن الهمام، مكتبة مصطفى الحلبي بالقاهرة. يح-فقه العقوبات في الثريعة الإسلامية - دراسة مقارنة-: د. عيسى العمري-د. محمد شلال العاني، العيك،

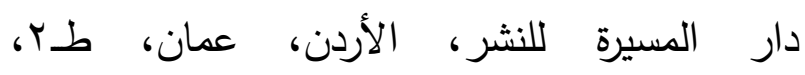
r 9 7-فلسفة العقوبة في الثريعة الإسلامية والقانون:

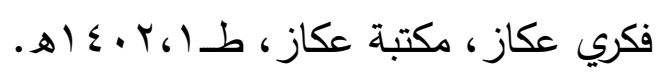
• - قانون العقوبات: عبود السراج، الكويت، مديرية الكتب، · أهـ اله 
7)

المفاهيم الحديثة في العقوبات البديلة عن الأحكام التعزيرية

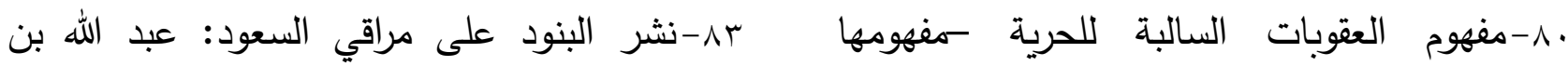
وفلسفتها-: د.مضواح بن محمد آل مضواح، جامعة إبراهيم العلوي الشنقيطي، المكتبة العصرية. نايف العربية للعلوم الأمنية. ع ـ-نصب الراية في تخريج أحاديث الهداية: جمال اي-مفهوم العقوبة وأنواعها في الأنظمة المقارنة: الدين عبد الله بن محمد بن يوسف الزيلعي، المكتبة

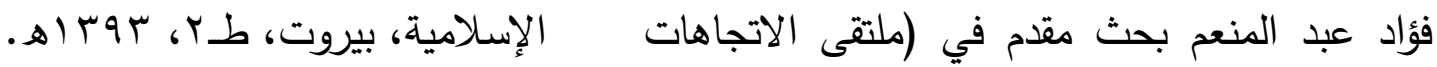

الحديثة في العقوبات البديلة) الذي أقامته وزارة العدل م-نظام التجريم والعقاب: علي علي منصور،

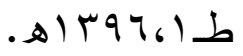

$$
\text { . } 1 \leqslant r / 11 / 19-1 V
$$

r r-مقاصد المعاملات ومراصد الواقعات: عبد الله

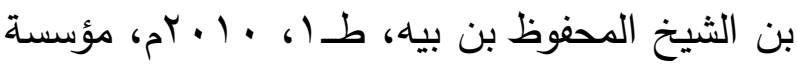
الفرقان للتراث الإسـامي، لندن. 


\title{
Modern Concepts Of Alternative Penalties To Discretionary Judgments
}

\author{
Dr. Anood Mohammad Alkhudairi \\ Assistant Professor, Department of Islamic Studies \\ College of Arts - Imam Abdulrahman Bin Faisal University
}

\begin{abstract}
Tazir rulings not authorized by the lawgiver and proving that it is sharia rulings, not a part of an opposite-sharia Secular law.The study also explained its concept, importance, limitations, and benefits, with identifying the corollaries maxims and the challenges preventing its implementation. Moreover, the study provided examples with identifying the relation between it and Tazir.

Results:

1- Based on the world current situation and that facts that have been proved by science concerning its great importance in archiving social stability, spreading peace, human rights, family cohesion, and national development, and its positive effect on the perpetrator and his purity from abuse and physical and psychological pains.

2- Alternative penalties are limited to Tazir, for which there is no sharia text determining the proper penalties.

3- Alternative penalties are characterized by: punching an perpetrator, giving a wide space for a judge to find the proper penalty for a crime or exchanging it with another.

Recommendations:

1- Raising the social awareness of alternative penalties importance, through organizing different courses and programs.

2- Asking for generalizing Taazir and Alternatives to imprisonment, in order to protect society and achieving the sharia objectives.

Key words: Penalties-Alternative-Taziria
\end{abstract}

